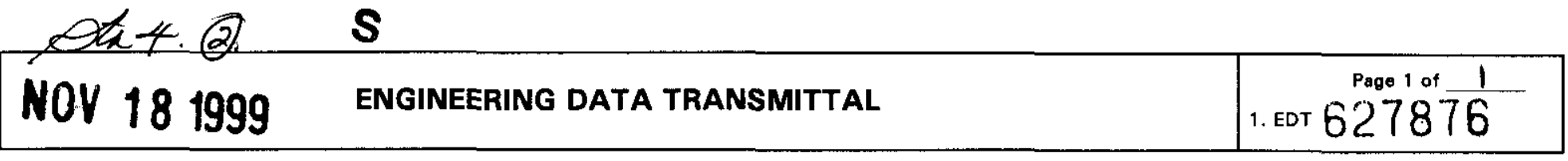

\begin{tabular}{|l|}
\hline $\begin{array}{l}\text { 2. To: (Receiving Organization) } \\
\text { Distribution }\end{array}$ \\
\hline $\begin{array}{l}\text { 5. Proj/Prog./Dept./Div.: } \\
\text { Core Sampling }\end{array}$ \\
\hline
\end{tabular}

3. From: (Originating Organtzation)
RPP Ugrade
$\begin{aligned} & \text { 6. Design Authority/Design Agent/Cog. Engr:: } \\ & \text { Rob Dale }\end{aligned}$

8. Originator Remarks:

Report of superficial hardness and other testing of pintle rods and retainer rings.

11. Receiver Remarks:

11A. Design Bacelino Document? $\bigcirc$ Yes $\mathrm{O}$ No
4. Related EDT No.:

N. A.

7. Purchase Order No.:

N.A.

9. Equip./Component No.:

N.A.

10. System/Bldg./Facility:

200G

12. Major Asem. Dwg. No.:

$\mathrm{H}-2-690140$

13. Permit/Permit Application No.:

N.A.

14. Required Responee Date: 14.

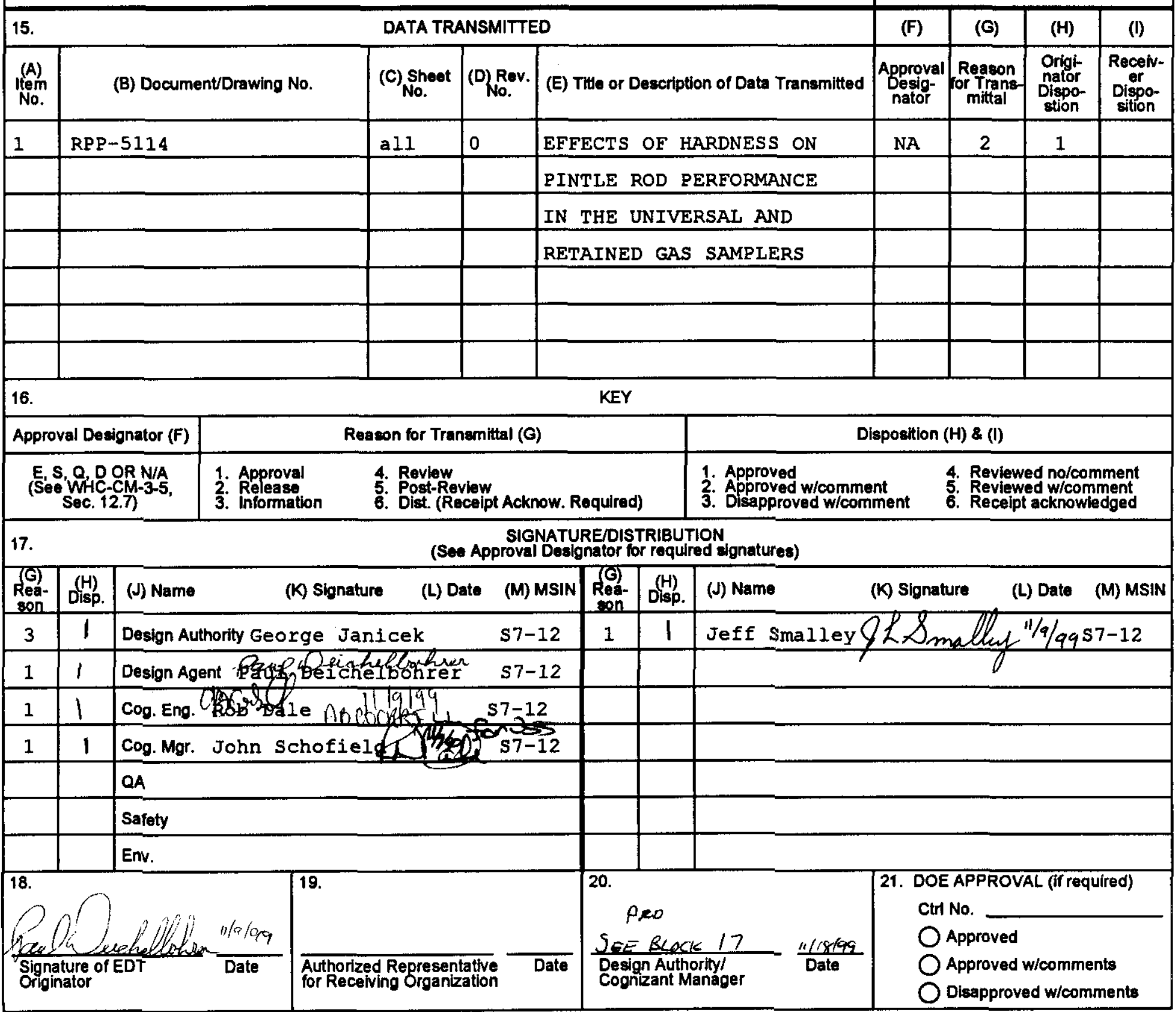




\title{
EFFECTS OF HARDNESS ON PINTLE ROD PERFORMANCE IN THE UNIVERSAL AND RETAINED GAS SAMPLERS
}

\author{
R.M. Bogex \\ Prepared by Lockheed Martin Hanford Corporation \\ Richland, WA 99352 \\ U.S. Department of Energy Contract DE-AC06-96RL13200 \\ L.7. 627876 \\ EDT/ECN: 2305 \\ Org Code: UH31000000 \\ B\&R Code: EW3120074 \\ UC: 2030 \\ Charge Code: 102250 EIO \\ Total Pages: 12064 \\ 槒,
}

Key Words: Universal Sampler, Release Disk, Superficial Hardness Rockwell

\section{Abstract:}

Interaction between hardness' of the pintle rods and the retainer rings used in the core samplers samplers is investigated. It is found that ordinary Rockwell $\mathrm{C}$ measurements are not sufficient and superficial hardness instruments are recommended to verify hardness since in-production hardness' of pintle rods is found to vary widely and probably leads to some premature release of pistons in samplers.

TRADEMARK DISCLAIMER. Reference hereln to any specific commercial product, process, or service by trade name, trademark, manufacturer, or otherwise, does not necessarly constitute or imply its endorsement, recommendation, or favoring by the United States Government or any agency thereof or its contractors or subcontractors.

Printed in the United States of America. To obtain copies of this document, contact: Document Control Services, P.O. Box 950, Mailstop H6-08, Richland WA 99352, Phone (509) 372-2420; Fax (509) 376-4989.

Beaver Heat Treating is a registered trade mark of Beaver Heat Treating Corporation.

Tinnerman is a registered trade mark of Eaton Yale \& Towne, Inc.

Officine Galileo is a registered trade mark of officine Galiles S.P.A. (Italy)
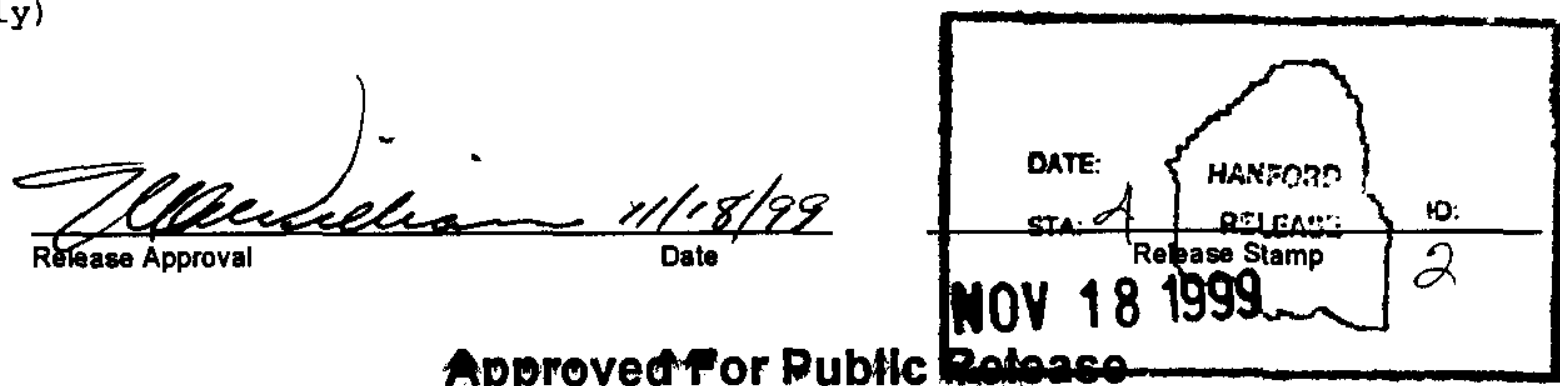
EFFECTS OF HARDNESS ON PINTLE ROD PERFORMANCE IN THE UNIVERSAL AND RETAINED GAS SAMPLERS

RPP-5114

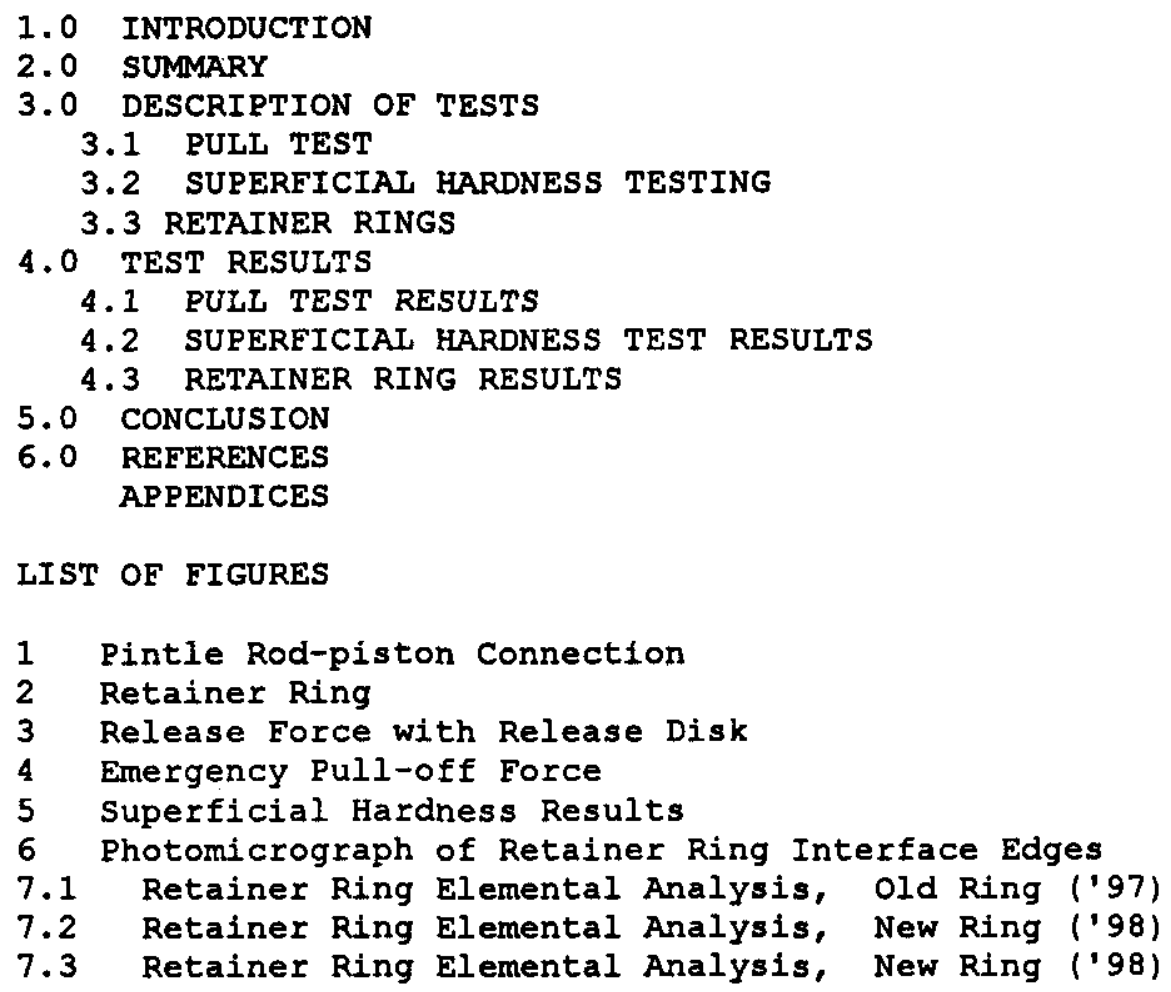




\subsection{INTRODUCTION}

Characterization of the waste in hanford underground storage tanks is necessary to maintain safe storage of the waste and to support design/planning of efforts to convert the waste into glass. Characterization of the waste is accomplished by drawing samples from the tanks and analyzing them at the analytical laboratory. Various methods are employed to obtain samples from the tanks based on the sampling objectives. Sometimes full core profiles of the waste are required. When this is the case, samples are taken with specially designed metal samplers which are operated by means of the Core Sampling Trucks.

There are four types of core samplers (Refs. 1, 2) used to obtain core samples, but the theroy of operation is the same regardless of the type.

In all of the samplers, a piston is connected to a pintle rod which holds the piston stationary during filling of the sampler. At the end of the filling stroke the pintle rod needs to be detached from the piston to allow the handling equipment (i.e, the remote latch unit) access to the top of the sampler. The pintle rod is connected to the piston by means of a sheet metal retainer ring (see Figs. 1 and 2). The ring is press-fit to the end of the pintle rod and captured by the piston in a groove near the top of the piston. The top surface of the groove, which interfaces with the retainer ring, contacts the outer edge of the retainer ring. In this way, force between the piston and the pintle rod deforms the ring (slightly) so that it grabs the rod.

At the end of the sampling stroke, the piston is released from the pintle rod by the release disk. The bottom of the release disk, which is shaped as a knife edge, transfers the force from the retainer ring's periphery to its interface/intersection with the pintle rod. When force is applied at this point the knife edge tends to pry the retainer ring from the pintle rod thus, releasing the piston.

In early FY'99 the samplers used in sampling waste tanks displayed a serious failure mode. After 3 years of successful operation, the piston-pintle rod connection of the sampler design was found to be unreliable--some pistons would not stay attached to the pintle rod; others would not release.

Characterization Engineering identified the problem to be associated with the control of pintle rod surface hardness. A heat treatment step was introduced into the fabrication of samplers which has greatly improved the piston-pintle rod performance.

A study into the superficial hardness of specimen pintle rods and retainer rings suggests that the current solution to the problem may not be completely satisfactory. It is recommended that the pintle rod-piston connection design be improved.

As part of the failure investigation, an in-depth study of the ability to reliably harden the pintle rod was initiated. This report present the results of this investigation. 


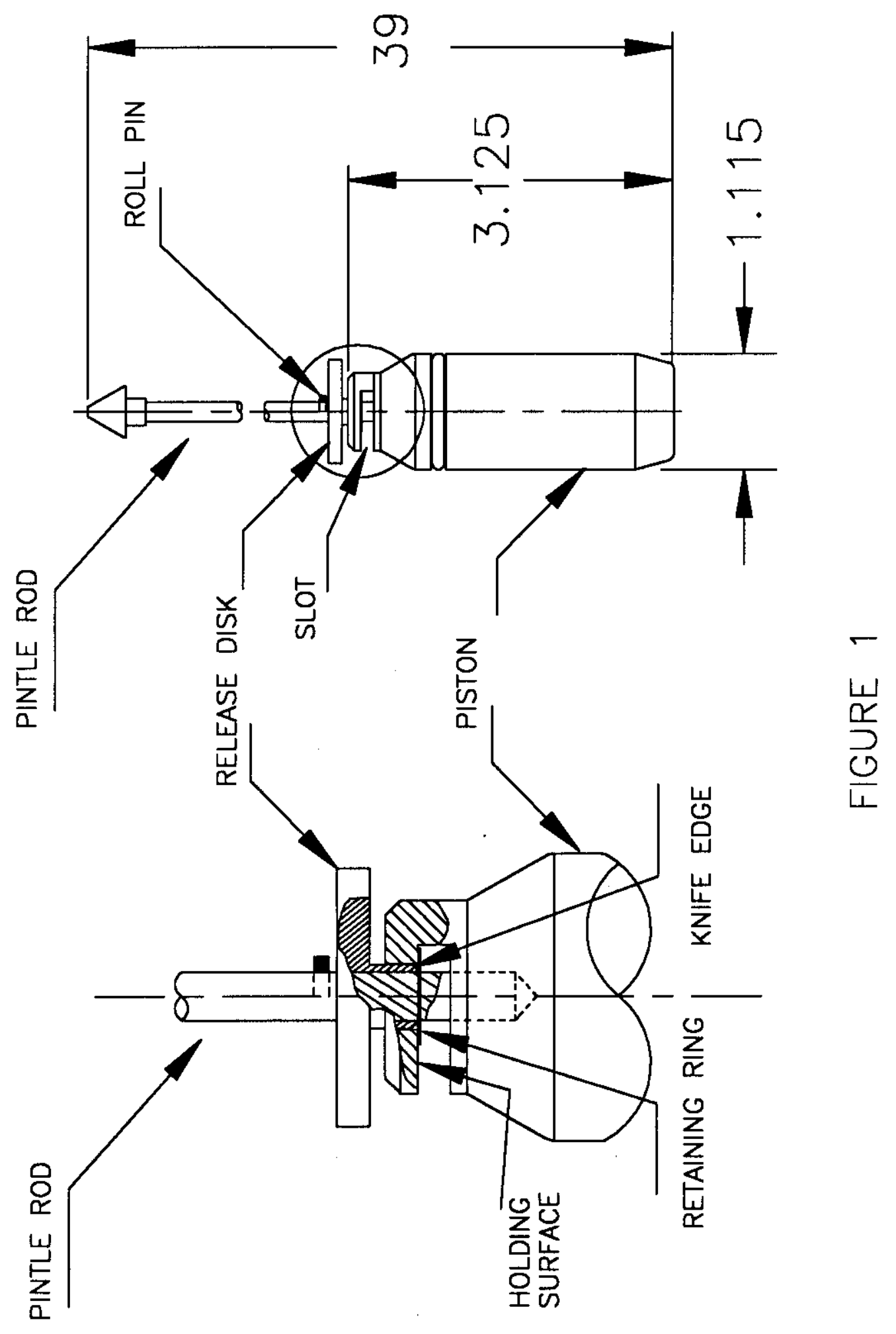


RPP-5114 Rev 0

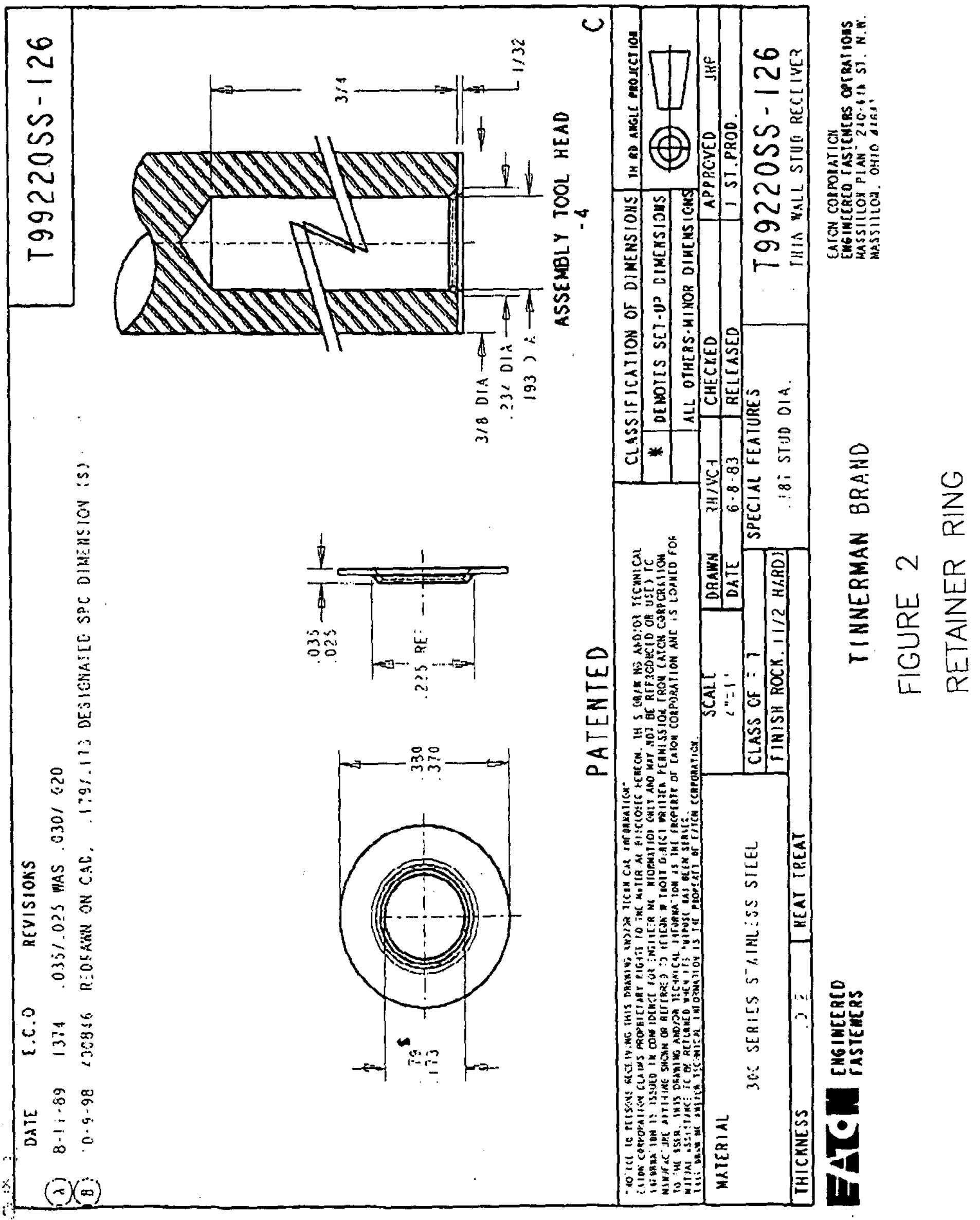


6 of 64

RPP-5114 Rev 0

\subsection{SUMMARY}

Haxdness testing of the current pintle rod material and of samples of old material suggest that the new material is harder than that used for sampler fabrication in 1996, probably caused by small differences in manufacturing of the rod material.

In a number of tests of the current pintle rod material, it was observed that the piston was released too easily. The old material performed successful for three years. Fully annealed pintle rods were observed to hold on to the retainer rings too tightly--sometime not releasing at all.

Heat treated samples with a variety of heat treating schedules were obtained. Testing revealed that heat treatment of $1100 \pm 50^{\circ} \mathrm{F}$ for $3 \pm .3$ hours provided pintle rods with the most satisfactory performance. Although, the hold and release parameters of these pintle rods were satisfactory, not all of the tested specimens met the "fail force" criteria (less than 200 pounds) The performance specification is described in Appendix A.1.

The tests were performed by installing a new retainer ring on to a test pintle rod specimen and measuring the force to pull it off with the satec machine in the 306 Building.

The superficial hardness of the pintle rods and retainer rings was measured on a variety of rods ( $33 \mathrm{pcs})$ with a variety of heat treatments and surface conditions. Hardiness of rings (23 pcs) was also tested. It is observed that for pintle rods of a common heat treat temperature, the minimum hardness readings are generally lower as the heat-treat temperature goes up. However, the maximum hardness readings are greater than any retainer ring.

A large fraction of the pintle rods heat treated to $1150^{\circ} \mathrm{F}$, or more, are softer than most of the retainer rings. Based on the concept that the rod should be somewhat softer than the retainer ring for proper operation, it is expected that heat treating to $1150^{\circ} \mathrm{F}$ will produce a significant fraction of pintle rod-ring pairs that operate properly. At the same time, heat treating to temperatures greater than $1150^{\circ} \mathrm{F}$ could produce a larger percentage of pintle rod-ring pairs that grip too tightly.

The sampler drawing has been ECN'd to require heat treating (and not annealing) of pintle rods. Beside heat treatment, the pintle rod-piston connection is now tested at several times during the life of the sampler. To date performance has been reported to be much improved, however, there have been some unsubstantiated reports of failure-to-hold. It has been postulated that the interference fit between the retainer ring and the pintle rod relaxes over time, for example, by means of metal creep.

\subsection{DESCRIPTION OF TESTS \\ 3.1 PULL TEST}

Samples of currently on-hand-pintle rod material were sent to Beaver Heat Treatingه, Portland, OR who treated the samples with a variety of heat treating schedules: $1050^{\circ} \mathrm{F}, 1100^{\circ} \mathrm{F}, 1150^{\circ} \mathrm{F}$, and $1250^{\circ} \mathrm{F}$. All of the heat treatments were held at temperature for three hours. Cooling was performed in an inert atmosphere. Beaver's measurement of the hardness of the samples were included with the temperature/time data received from Beaver. 
7 of 64

RPP-5114 Rev 0

The samples were tested on the satec machine in 305/300. The tests were performed by installing a new retainer ring on to a test pintle rod specimen and then the force to pull the ring off, either with or without the release disk, was measured with the satec machine. Since a retainer ring can be used only once, each of the pull tests on an individual pintle rod specimen are performed with a different retainer ring.

\subsection{SUPERFICIAL HARDNESS TESTING}

As discussed in Appendix A.2, the validity of the hardness values submitted by Beaver may be questioned. The readings were taken with a Rockwell C instrument which is not expected to provide reliable results on rods as small as the pintle rods. Improved hardness readings can be made with a superficial hardness testers.

A selection of 33 pintle rods and 23 retainer rings were studied utilizing a superficial hardness tester (Officine Galileo, Firenze, Italy). A description of superficial hardness testing and its advantages can be found in Appendix A.2. The samples were drawn from: the heat-treated specimens prepared by Beaver Heat Treating(, failures from the field, failures from manufacturing and non-failures. The sources of the pintle rods and rings are summarized in section 4 and greater detail on the rod's and retainer ring's histories can be found in the appendices.

Pintle rods in the universal sampler have their ends roughened ostensibly to improve the holding force. The samples obtained from Beaver Heat Treating were tested without roughening, i.e., smooth. However, three samples were tested with their ends knurled.

Hardness measurements were taken at a number of locations on the test pieces. Also, the different surface preparations were hardness-tested. Besides the roughening of the pintle rod ends with a thread chasing file (Ref. 1) tests were conducted on knurling, and machine brushing. In cases of used pintle rods, the original retainer ring left a scrapped region on the end of the rod when it was pulled off. Heat treated pintle rod samples from Beaver are discolored (lightly oxidized). Bluish and brownish surfaces are found on the samples depending upon the heat treat cool-down atmosphere. Details of the tests can be found in the appendices referenced.

\subsection{RETAINER RINGS}

The manufacturer of the retainer ring (Eaton Industries(B, Cleveland, $O H$ ) was contacted and the design of the piston-pintle rod connection was discussed with their applications engineers. Samples of failed rings were sent to Eaton for analysis.

Rings from two failed samplers and from one old sampler (which operated correctly) were examined microscopically. The rings were "mounted" and sectioned to reveal the contour of the edge that interfaces with the pintle rod (the gripping edge). Also, the mounted specimens were analyzed for different alloy content in a scanning electron microscope.

Superficial hardness of the retainer rings was also measured. 
4.0 TEST RESULTS

8 of 64

RPP-5114 Rev 0

4.1 PULL TEST RESULTS

Pull test results are shown in Figures 3 and 4 . Hardness values were provided by Beaver Heat Treating. The values were obtained with a Rockwell $\mathrm{C}$ instrument.

Since a retainer ring can be used only once, each of the data points in Figures 3 and 4 are taken with a different retainer ring. The force readings are presented in descending order (i.e., there is no significance associated with the abscissa). It should be observed that the forces generally overlap independent of heat treatment of the pintle specimen. No particular pattern is apparent: for example, the curve of the softest pintle ( $R C=13 ; 1250^{\circ} \mathrm{F}$ ) lies close to that of he hardest $\left(R c=22 ; 1050^{\circ} \mathrm{F}\right)$, see Figure 3 . In Figure 3 , Normal Release Force, there is some suggestion that harder pintle release more easily, except for the results of the $\mathrm{Rc}=20$ specimen which is the second-softest material and has the largest release force.

As discussed in Appendix A.2, the validity of these hardness values may be questioned. The readings were taken with a Rc weight/indenter which is not expected to provide reliable results on rods as small as the pintle rods. Consequently, the hardness of the rod consistently producing forces greater than the other samples (diamond data points, Figs. 3 and 4), may not be actually be $\mathrm{Rc}=20$.

Pintle rods in the universal sampler have their ends roughened ostensibly to improve the holding force. The samples in Figures 3 and 4 were tested without roughening, i.e., smooth. However, three samples were tested with their ends knurled. As can be seen in Figures 3 and 4 there is not much difference in performance.

In spite of a lack of a clear association between heat treatment and release forces, it should be pointed out that all of the normal release forces are less than 100 pounds and are, thus, "in spec" according to Appendix A.1. Also, it should be noted that most of the emergency pull-out forces (Fig. 4) are above 200 pounds and, thus, "out of spec".

This excessive emergency pull-out force is considered to be a relatively small risk to sampling operations. Such high forces would be expected of the drill truck draw works only if some other failure occurred down in the drill string which would seize the piston and keep it from contacting the spring stops.

\subsection{SUPERFICIAL HARDNESS TEST RESULTS}

Results of superficial hardness testing are summarized in Table I. Details of the testing/results are found in the appendices which are called-out in the Table. A description of the rod/ring sample is given along with an identification number. For each sample the range of superficial hardness results is given.

The results are graphically illustrated in Figure 5. The ranges of hardness readings for the different heat-treated samples versus the heat treatment temperatures are displayed. Readings were taken at a wide variety of locations. The readings at similar surface conditions are grouped into a common vertical line (with median reading marked with a circle, diamond, 


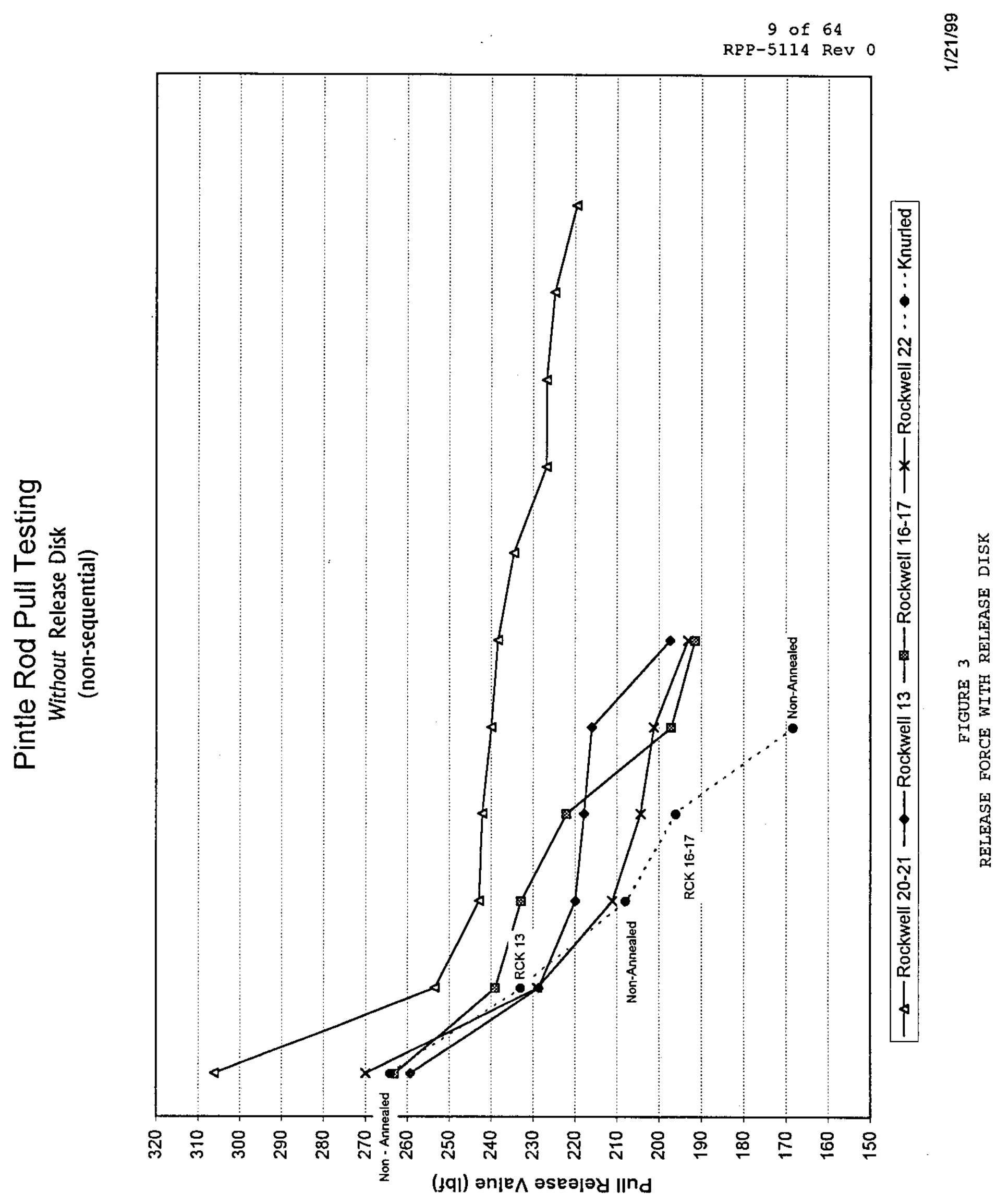




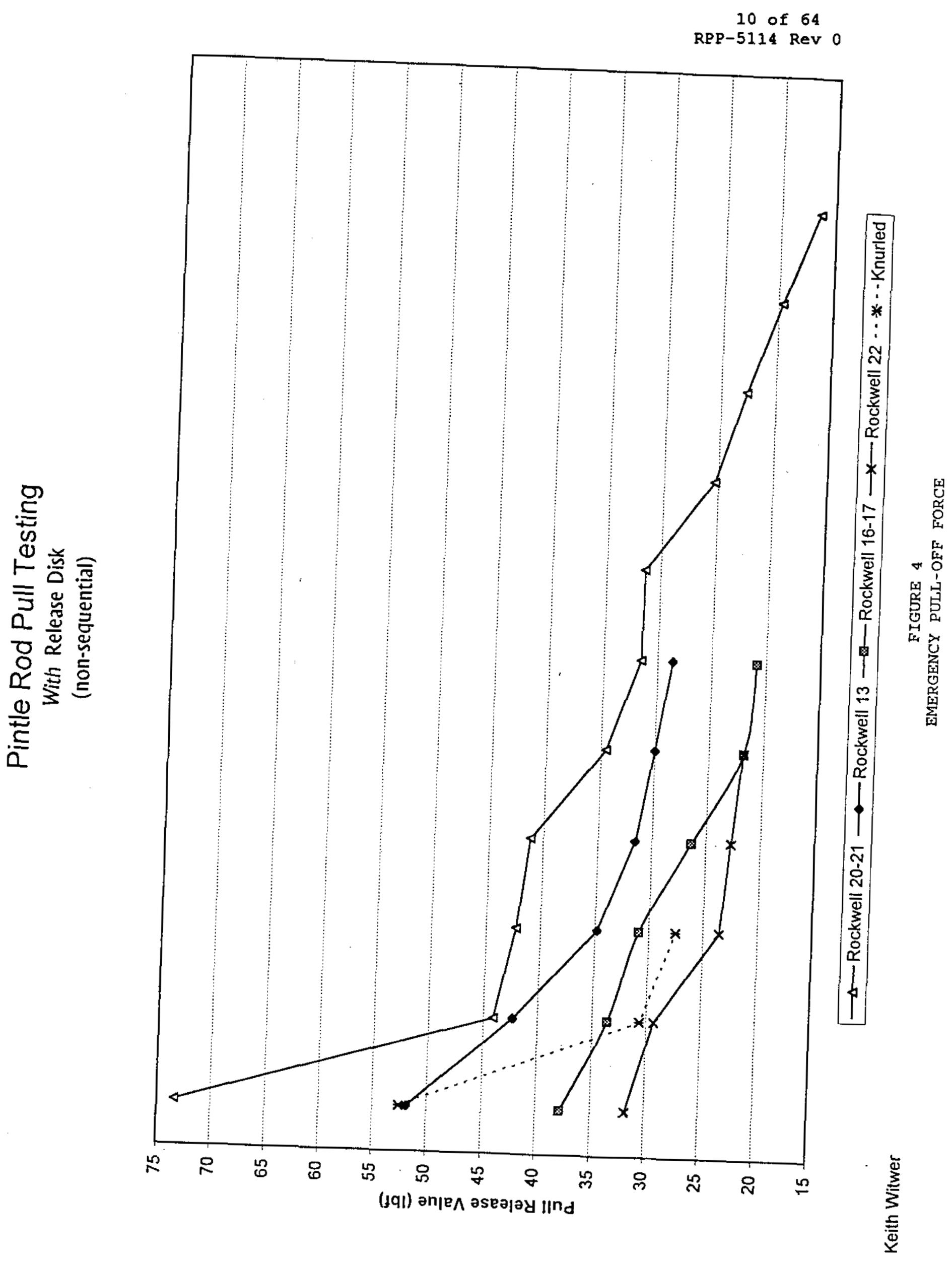


11 of 64

RPP-5114 Rev 0

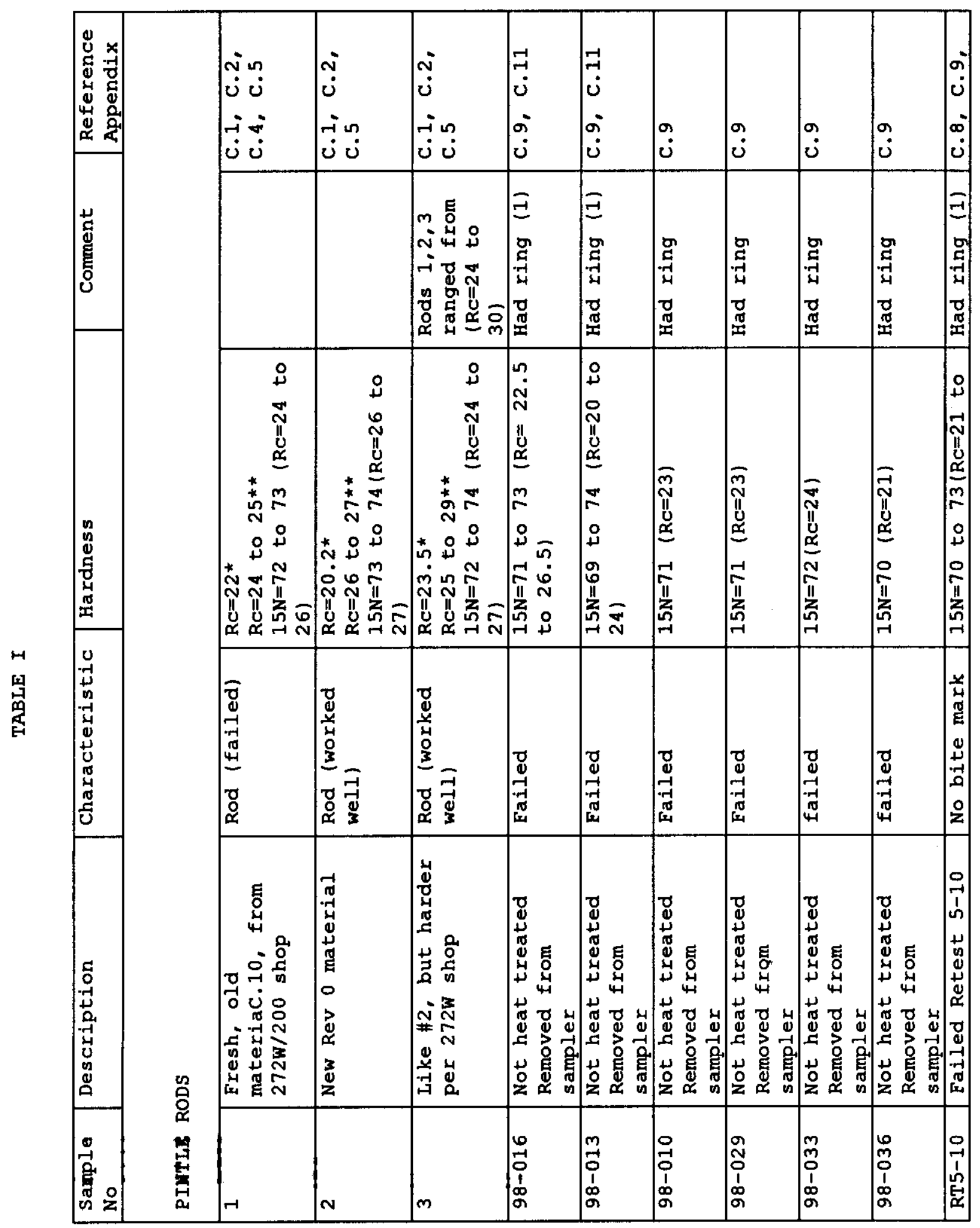




\begin{tabular}{|c|c|c|c|c|c|c|c|c|c|c|c|c|c|c|}
\hline$\left|\begin{array}{l}-1 \\
-1 \\
ن\end{array}\right|$ & 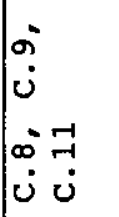 & $\begin{array}{l}a \\
ن \\
0 \\
0 \\
ن\end{array}$ & 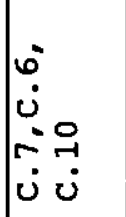 & 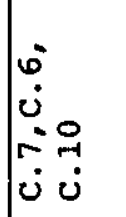 & 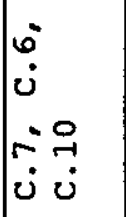 & 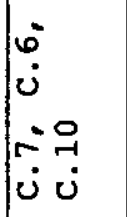 & 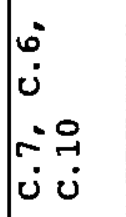 & 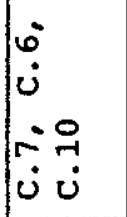 & 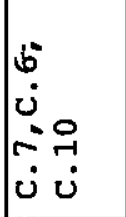 & $\begin{array}{l}0 \\
0 \\
0 \\
0 \\
0 \\
0\end{array}$ & 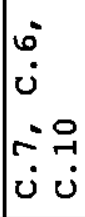 & ن. & $\int_{0}^{0}$ & ن. \\
\hline & 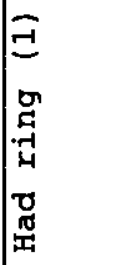 & 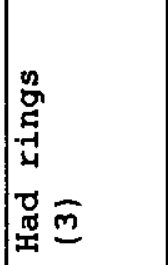 & & & & & & & & & & & & \\
\hline 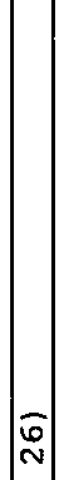 & 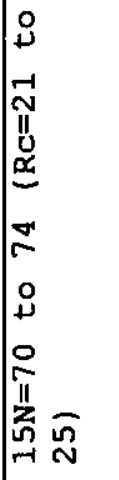 & 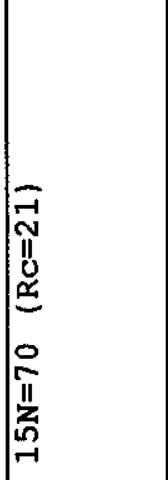 & 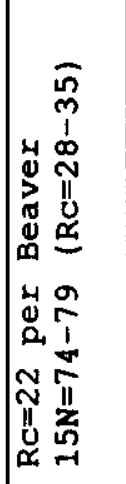 & 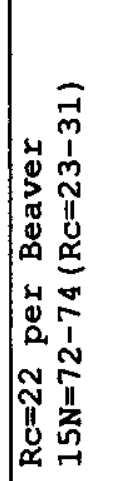 & 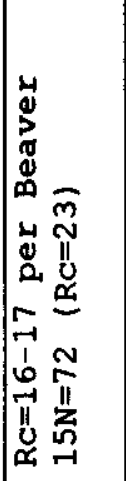 & 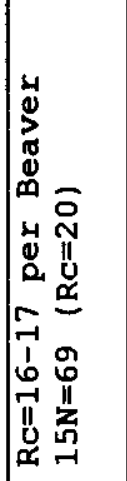 & 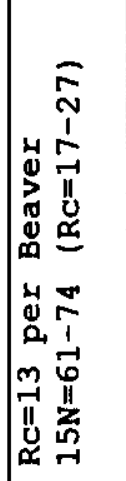 & 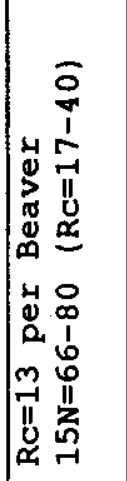 & 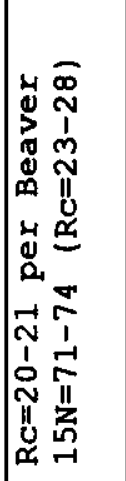 & 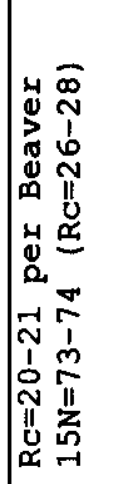 & 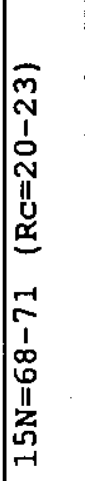 & & & \\
\hline 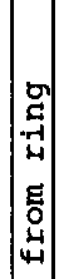 & 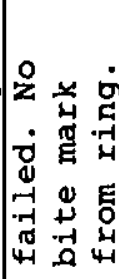 & 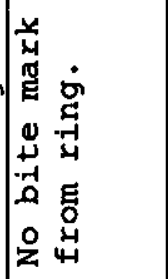 & 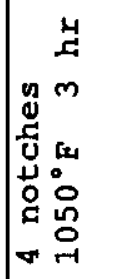 & 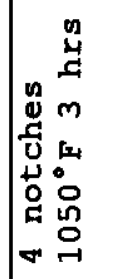 & 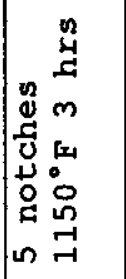 & 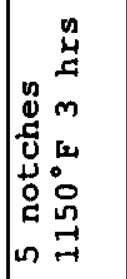 & 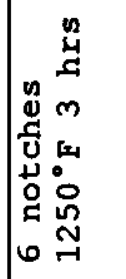 & 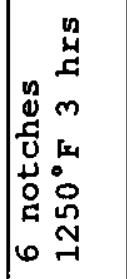 & 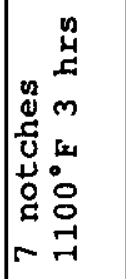 & 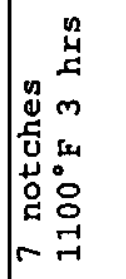 & \begin{tabular}{l}
4 \\
\multicolumn{1}{c}{} \\
$m$ \\
$m$ \\
5 \\
0 \\
8 \\
0 \\
-1 \\
-1
\end{tabular} & $\begin{array}{l}4 \\
x \\
m \\
m \\
51 \\
0 \\
0 \\
0 \\
-1 \\
-1\end{array}$ & \begin{tabular}{l}
4 \\
\multicolumn{1}{c}{} \\
$m$ \\
$m$ \\
5 \\
0 \\
0 \\
0 \\
-1 \\
-1
\end{tabular} & $\begin{array}{c}4 \\
c \\
m \\
m \\
5 \\
0 \\
8 \\
0 \\
-1 \\
-1\end{array}$ \\
\hline 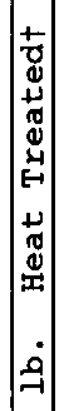 & 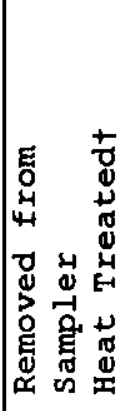 & 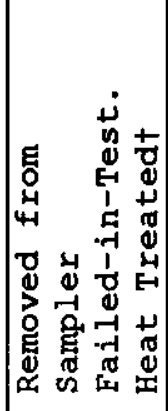 & 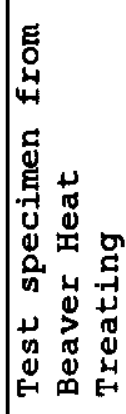 & 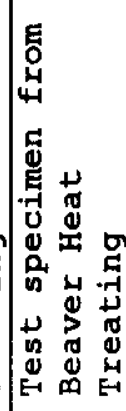 & 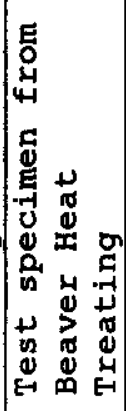 & 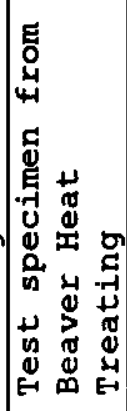 & 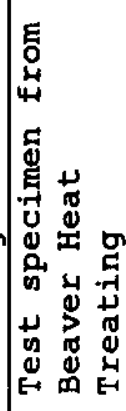 & 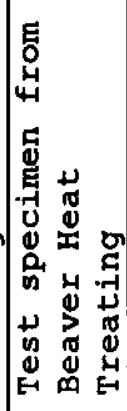 & 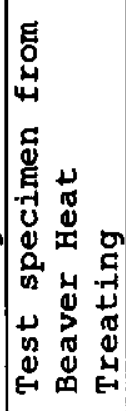 & 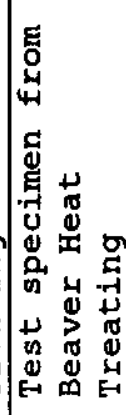 & 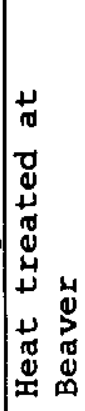 & 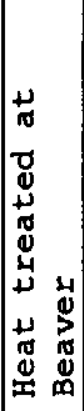 & 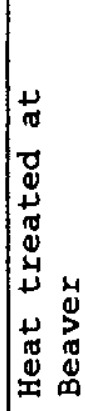 & 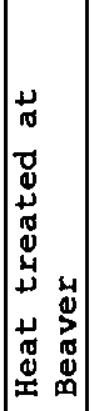 \\
\hline & $\mid \begin{array}{l}\not \\
m \\
0 \\
1 \\
\infty \\
\sigma\end{array}$ & $\mid \begin{array}{l}-1 \\
1 \\
- \\
-1 \\
1\end{array}$ & $\begin{array}{l}\overrightarrow{1} \\
\mathbf{z} \\
\mathbf{z}\end{array}$ & $\begin{array}{l}\mathbf{w} \\
\mathbf{1} \\
\mathbf{z}\end{array}$ & 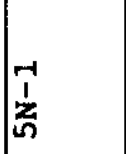 & in & $\mid \begin{array}{l}-1 \\
\frac{1}{z}\end{array}$ & $\begin{array}{l}w \\
1 \\
z\end{array}$ & $\frac{1}{2}$ & $\begin{array}{l}\boldsymbol{N} \\
1 \\
z\end{array}$ & 辛 & $\mid \begin{array}{c}1 \\
1 \\
0 \\
9 \\
a\end{array}$ & 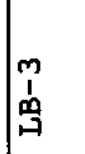 & 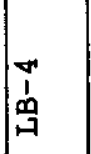 \\
\hline
\end{tabular}




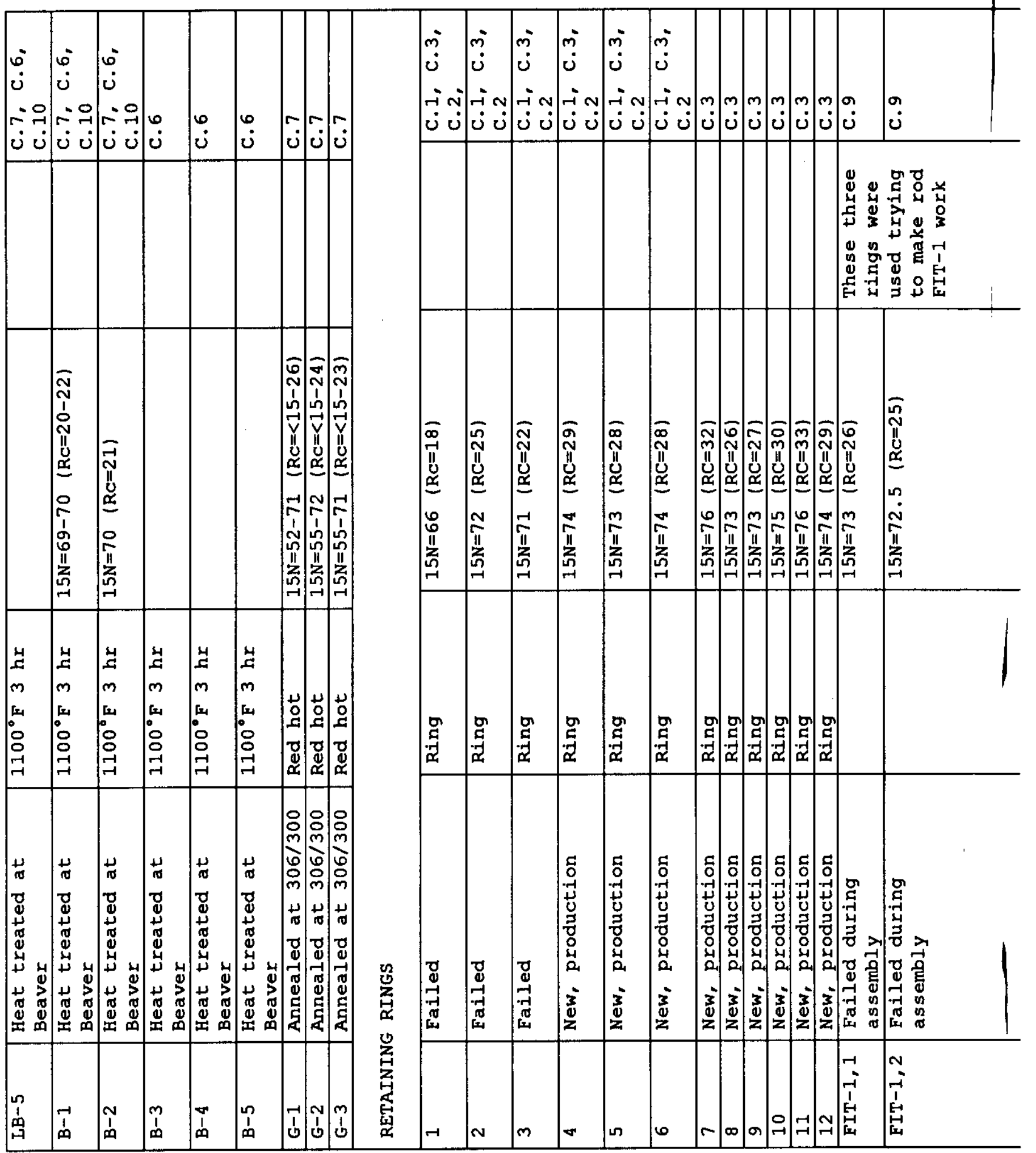




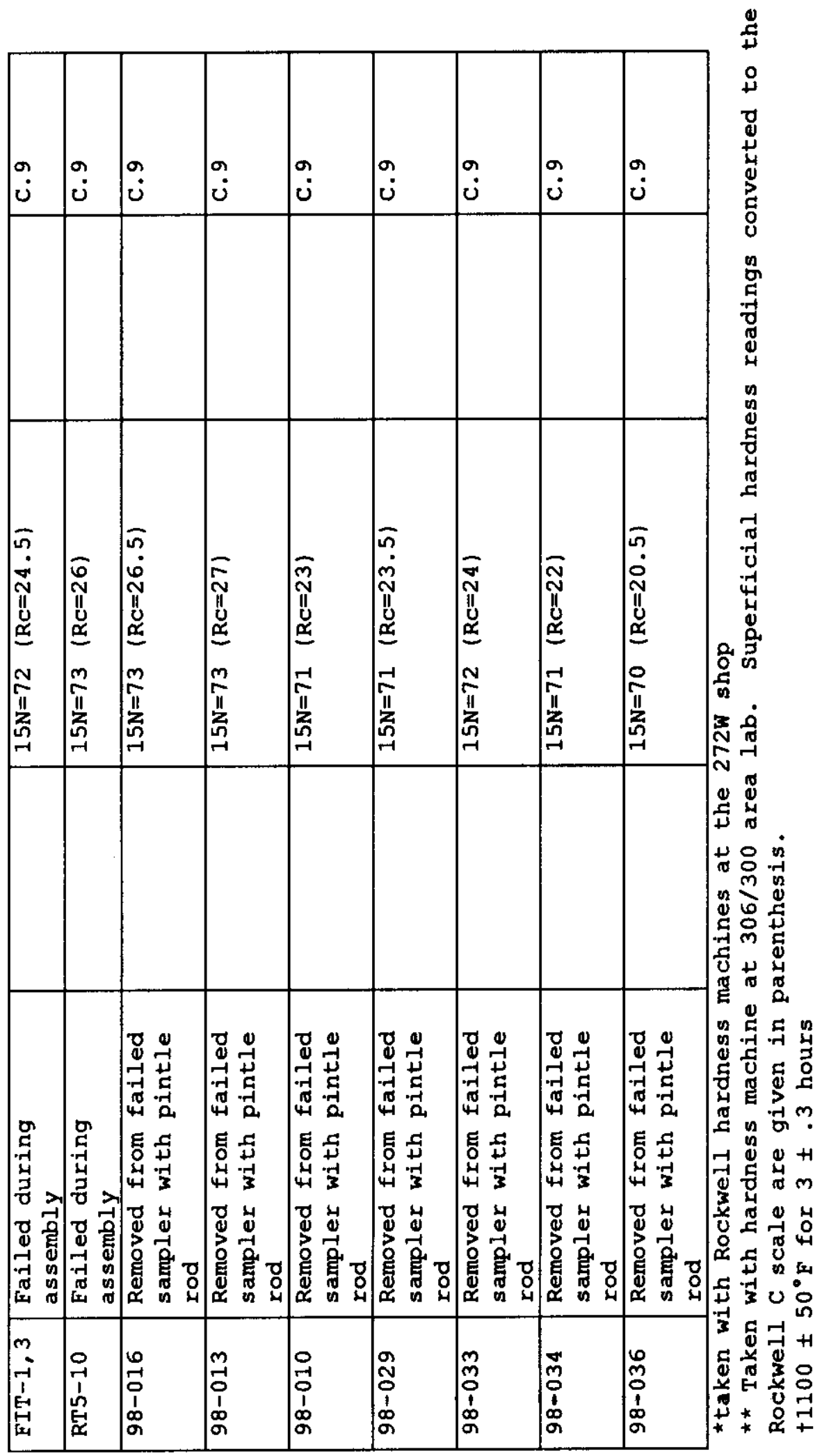


RICKWELL C HARDNESS

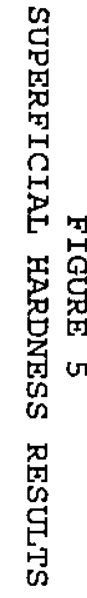

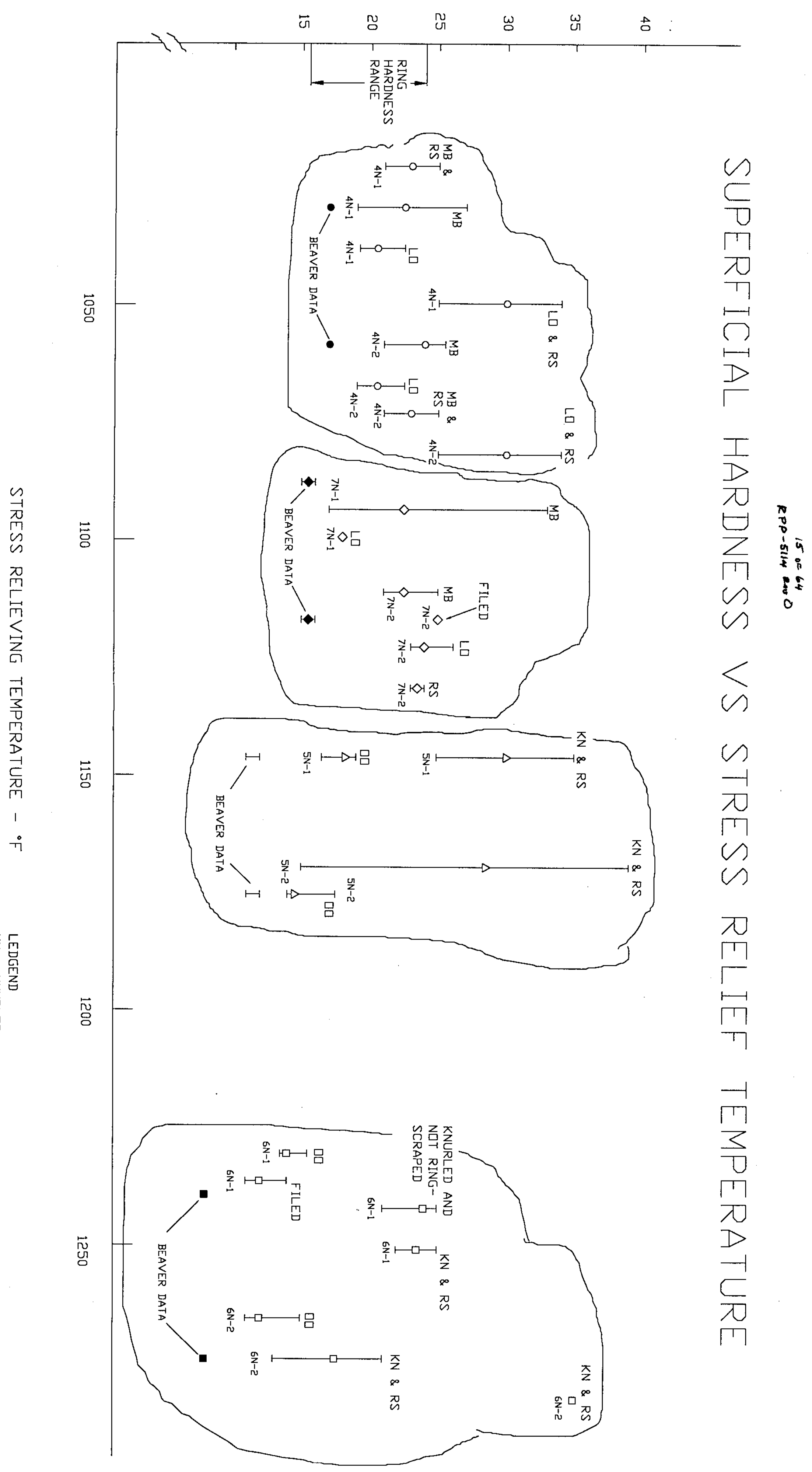

品和怒否留

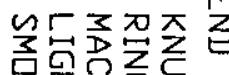

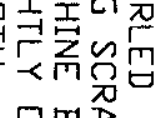

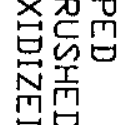

ia 
etc.) Samples which were heat treated at a common temperature are grouped in a common "cloud".

The hardness readings were taken with the superficial hardness tester and the readings were converted to the equivalent Rc readings. It should be noted that the hardness reading obtained by Beaver Heat Treating, which were obtained with an ordinary Rockwell C hardness instrument, are also plotted in Figure 5. The Beaver readings are consistently below the superficial readings, presumably, because the rod diameters are too small for proper use of the Rockwell $\mathrm{C}$ indenter/weights.

Figure 5 shows that the minimum hardness readings are generally lower as the heat-treat temperature goes up. However, the maximum readings are all on the order of $\mathrm{RC}=35$.

\subsection{RETAINER RING RESULTS}

In communication with the ring factory (Eaton Industries, Cleveland, $\mathrm{OH}$ ) their applications service suggests that the ring was not designed to be used in a "hold and remove" application. The ring was intended to be put on and left on. Samples of failed rings were sent to Eaton who found nothing wrong with them.

Results of the photomicroscopy study of the rings' interfacing edge are shown in Figure 6. The rings are cut through the centerline and the cut surface (.020 width) is shown magnified by $\times 100$. The photo designated "97" is of a ring that functioned properly. Photos marked "98" are from the marginal performance population. No difference between the rings that fail and the one that worked properly is apparent.

Elemental analysis of the rings is shown in Figures $7.1,7.2$ and 7.3 . Figure 7.1 illustrates the composition of old rings which are from the time period during which the piston-pintle rod connections worked well. Figures 7.2 and 7.3 are newer from the period of time of the piston-pintle rod failures. Both the failed rings and the functional ring have, essentially, the same elemental make-up.

Superficial hardness reading of the retainer rings suggests that the ring hardness varies over a great range. At the left edge of Figure 5, the hardness range observed for the retainer rings is indicated. It can be seen that the maximum hardness for pintle rods is greater than any retainer ring. But, some of the pintle rods which have been heat treated to $1150^{\circ} \mathrm{F}$, or more, are softer than most of the retainer rings. Based on the concept that the pintle rod should be somewhat softer than the retainer ring for proper operation, Figure 5 suggests that heat treating to $1150^{\circ} \mathrm{F}$ will produce a significant fraction of pintle rod-ring pairs that operate properly. However, a fraction of the pintle rods will be expected to be too hard to engage the retainer ring sufficiently.

At the same time, heat treating to temperatures greater than $1150^{\circ} \mathrm{F} \mathrm{could}$ produce a larger percentage of pintle rod-ring pairs that grip tightly. But, as was observed with the retained gas sampler, it may be difficult to release the grip with the release disk if the heat treatment temperature is too high. 


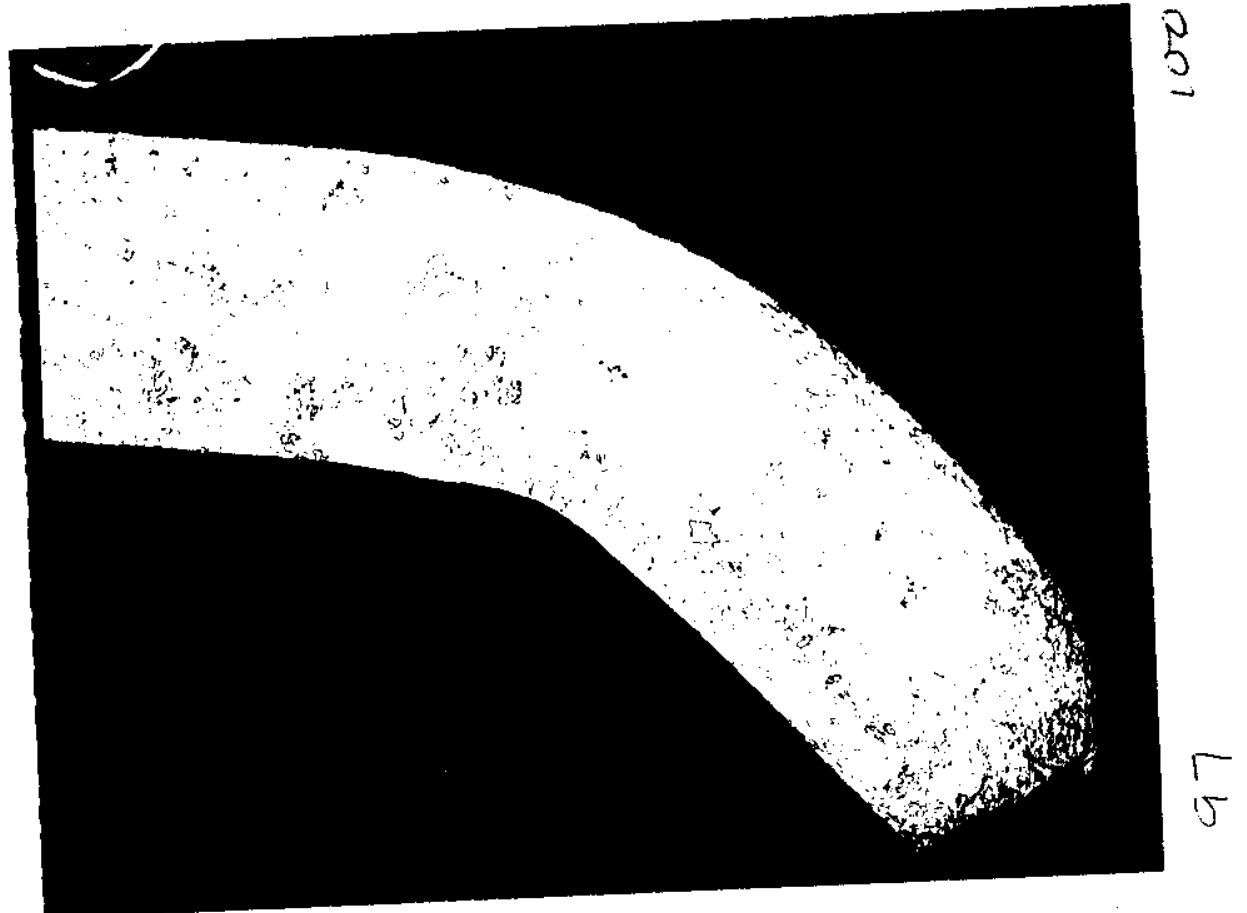

17 of 64

RPP-5114 Rev 0

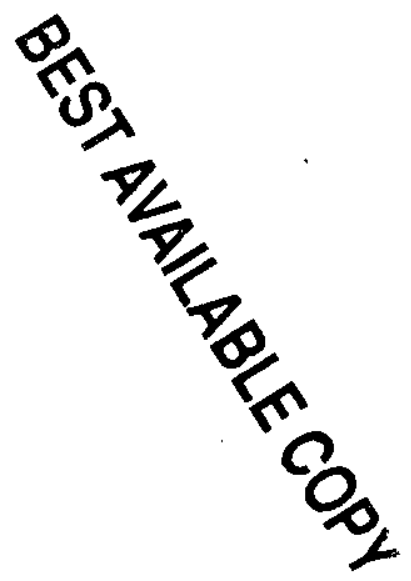

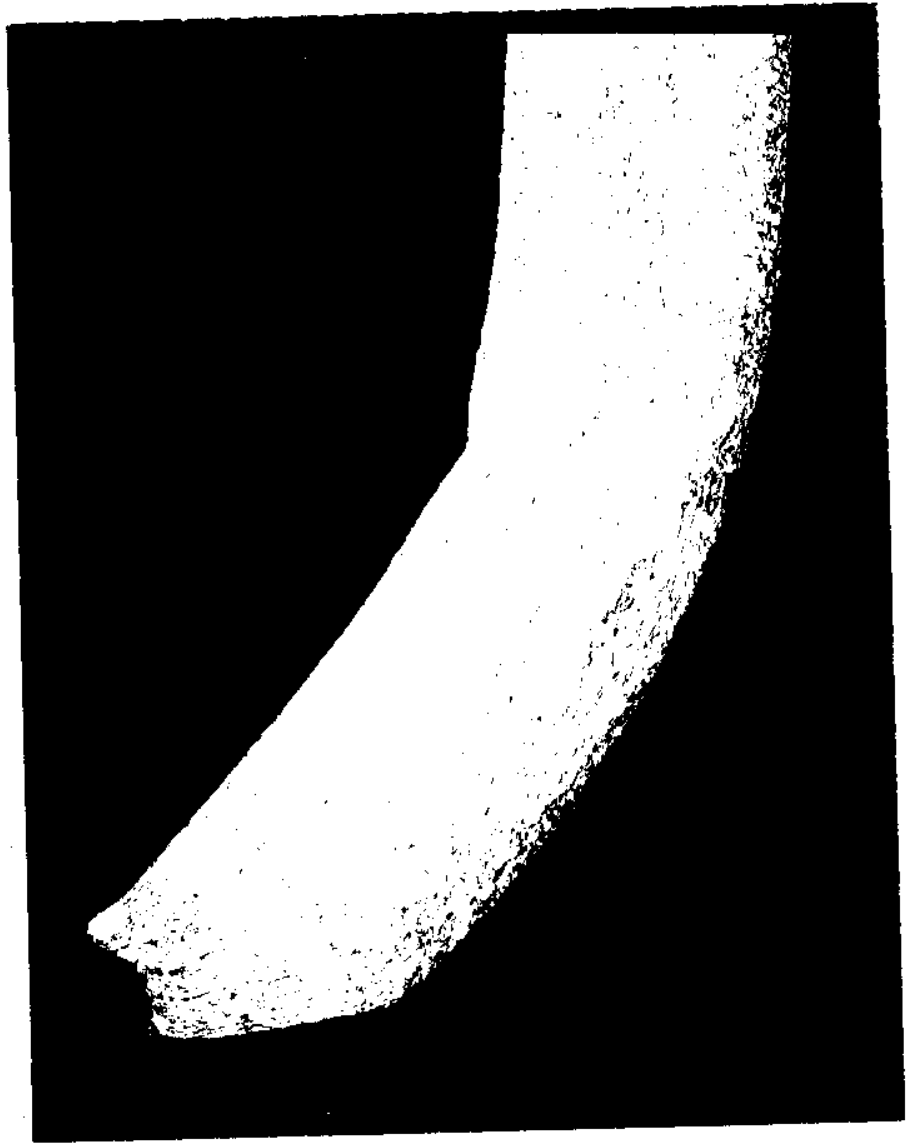

1198

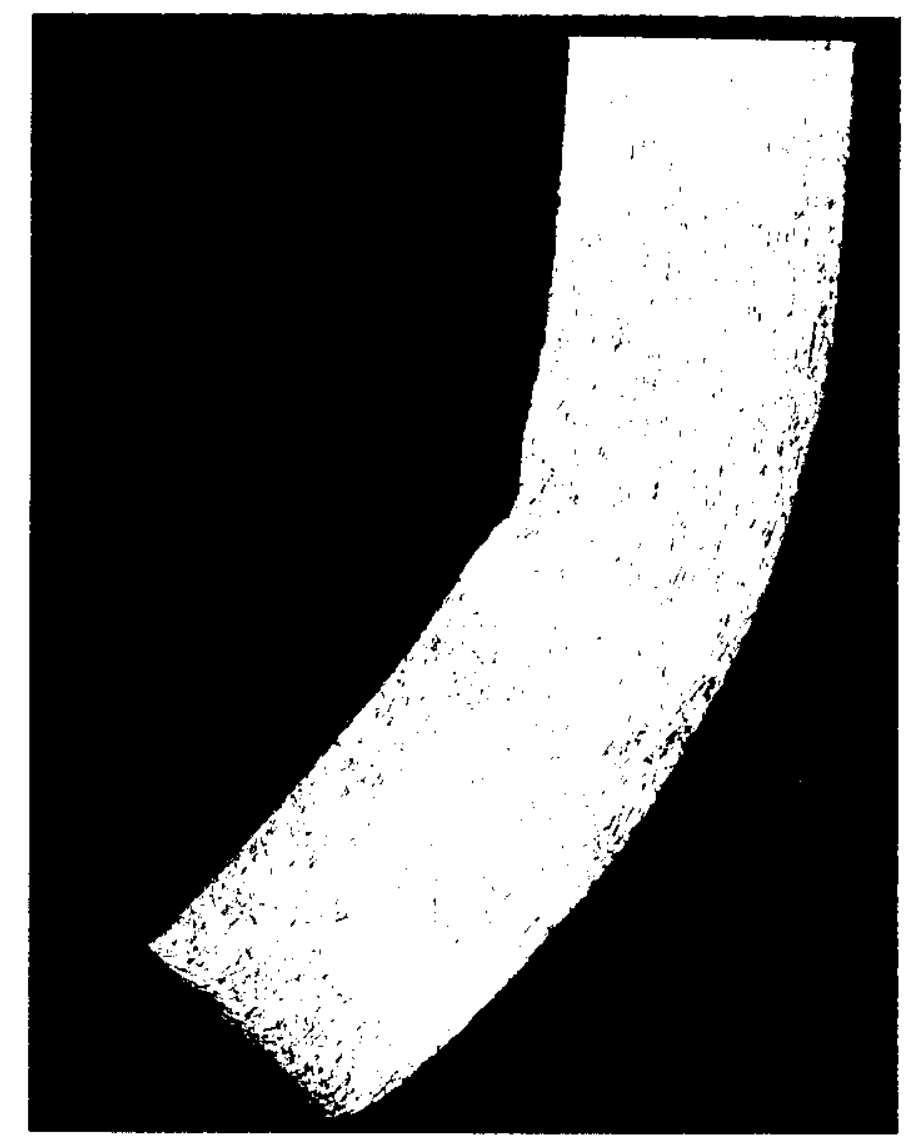

$100 x$

FIGURE 6

PHOTOMICROGRAPH OF RETAINER RING INTERFACE EDGES

Section of Edge. Irregular Edge is outer Edge of Hole. Ring designated "97" is from the batches of rings the functloned properly. The "1298" and "1198" are from batches that malfunctioned. Essentially no difference is apparent among the samples. 
BATTELLE-PNNL PSL/SEM

Cursor:10. 230keV $=36$
TUE 29-DEC-98 16:06

ROI (1) 0.000:0.000

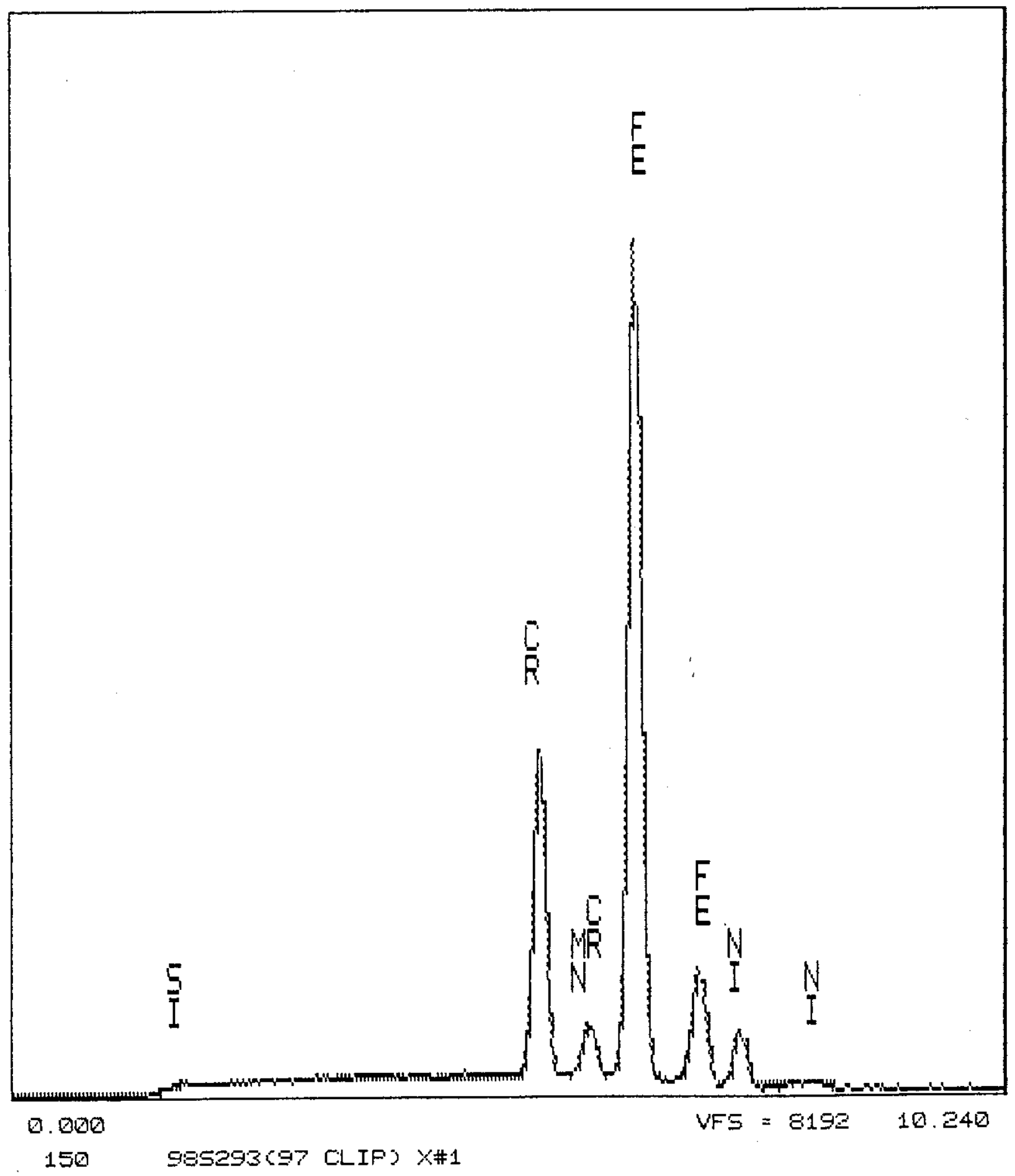

FIGURE 7.1

RETAINER RING ELEMENTAL ANALYSIS

Ring from old stock (worked) 
BATTELLE-FNNL PSL/SEM

Cursor:10.230keV $=58$
TUE $23-0$

(1) $0.000: 0.000$

ROI

$E$
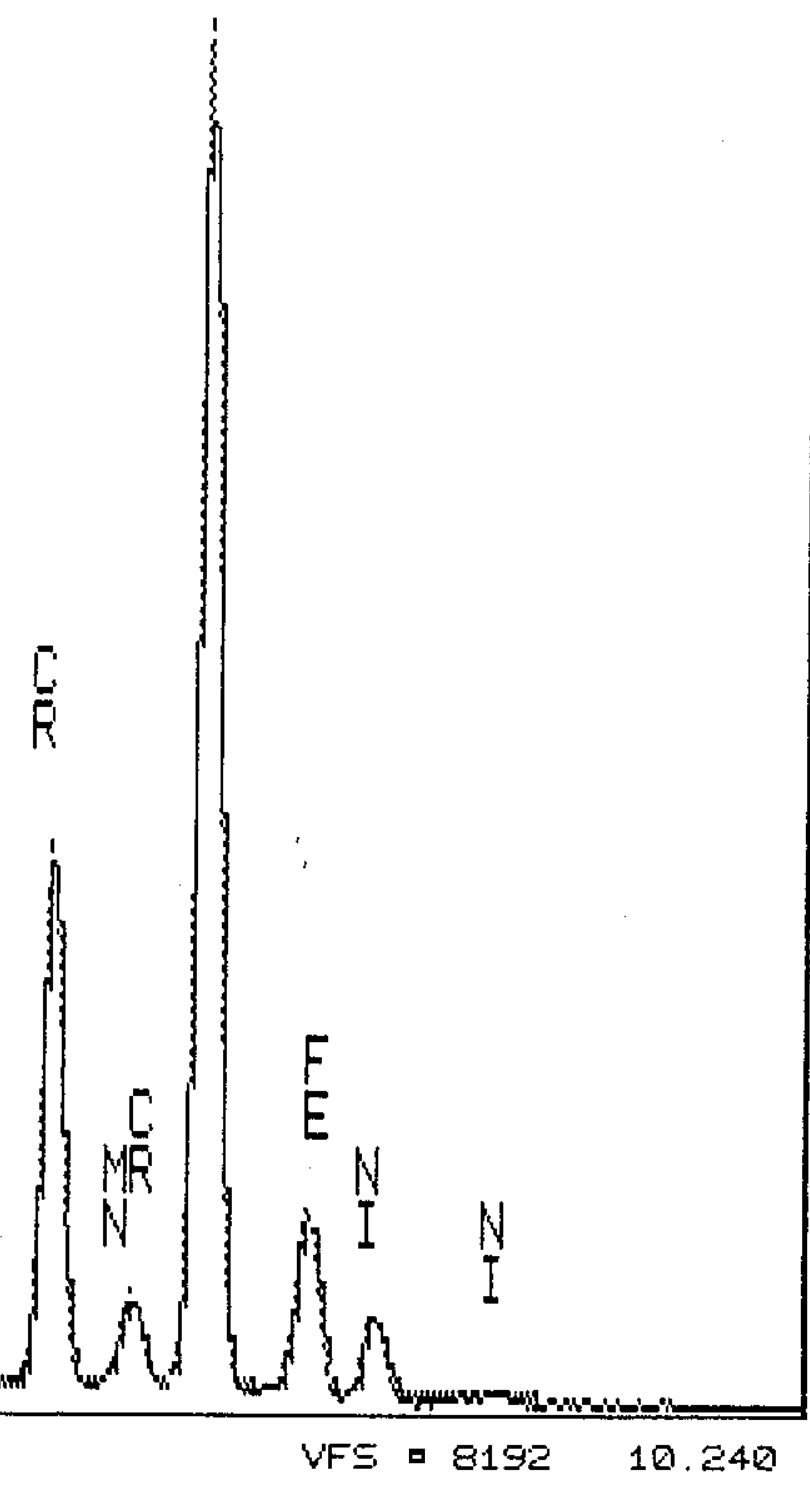

150

$989294(11 / 98$ CLIP) $x \# 1$

FIGURE 7.2

RETAINER RING ELEMENTAL ANALYSIS

Ring from New stock (problematical) 


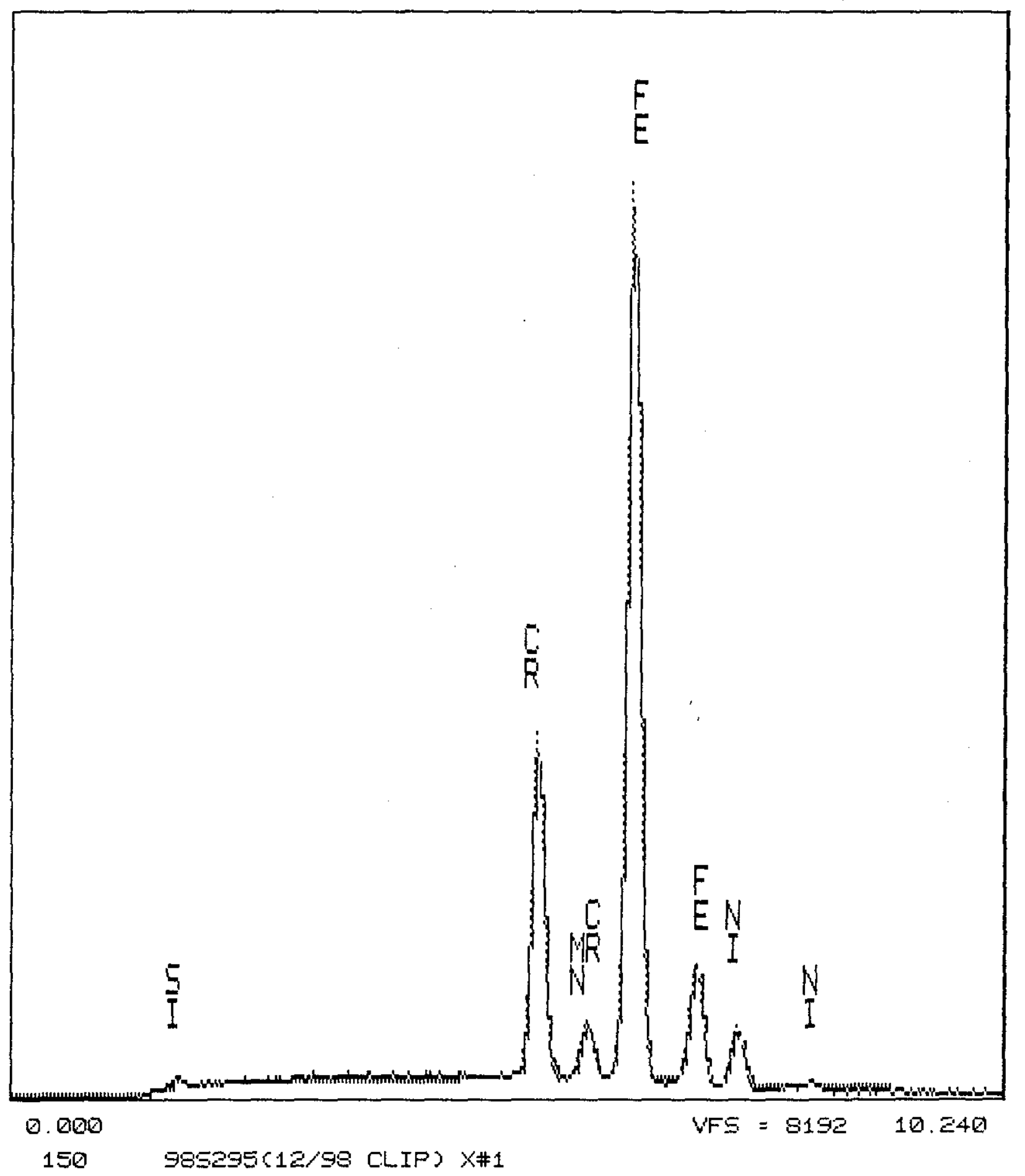

FIGURE 7.3

RETAIER RING ELEMENTAL ANALYSIS

Ring from New stock (problematical) 


\subsection{CONCLUSION}

The severity of the failure of piston-pintle rod connection in samplers has largely been mitigated by heat treating the pintle rod as part of the

fabrication process. However, room for improvement appears to be available:

- emergency pull-out force is excessive for a significant fraction of samplers

- failure-to-hold failures seem to be not completely eradicated.

- potentially aging the samplers in storage contributes to creep which could induce early release failures.

- pintle rod hardness depends upon a relatively precise heat treatment procedure and could be being influenced by other, unknown, factors

- the metallurgical properties of the retainer ring are relatively out-ofcontrol since the manufacturer does not intend for them to be used in an install-and-remove application such as the piston-pintle rod connection.

- Because of these uncertainties the piston-pintle rod connection should be redesigned to reduce its dependence on material properties. 
6.0 REEERENCES

6.1 Universal Sampler Drawing H-2-690140

6.2 Retained Gas Sampler Drawing H-2-821608

6.3 RPP-4782 Development of the Pintle Release Fork Mechanism, 1999

6.4 Hardiness Tester and Accessory Instruction Book, Officine Galileod, Firenze, Italy (1977)

6.5 ANS z115.6 E18-74"Standard Test Methods for Rockwell Hardness and Rockwell Superficial Hardness of Metallic Materials" 


\section{APPENDIX}

\section{A. 1 PERFORMANCE SPECIFICATION}

The piston-pintle rod holding force requirement must be at least 120 pounds so that the piston does not come loose under the action of the hydrostatic head forces experienced during sampler change out.

The fail force must not be greater than 200 pounds because if the piston were to get stuck in the sampler below the spring stops, the core sample truck draw works would have to force the pintle rod out of the piston. Forcing it out with more than 200 pounds would damage the core sample truck draw works.

\section{A. 2 HARDNESS TESTING}

As explained in Reference 4, the retainer ring is designed to "bite" into the pintle rod to form the piston-pintle rod connection. If the pintle rod is too hard, or if the retainer ring is too soft, the bite may not be effective.

Measurement of retainer ring hardness presents technical difficulties because the ring is made of .02-thich material.

\section{A.2.1 NORMAL ROCKWELL TESTERS}

Rockwell hardness testers utilize a hard "indenter" which is pressed into the metal in a controlled manner. First, an initial load of $10 \mathrm{~kg}$ is applied pressing the indenter into the metal. Then a standard force is added 160 , 100 or $150 \mathrm{~kg}$ depending upon the Rockwell scale) to the initial load and removed. The increase in penetration, relative to the initial indent, in multiples of 2 microns is the Rockwell hardness reading.

The standard force along with the particular indenter used distinguishes one Rockwell scale from another. For example:

\begin{tabular}{|c|l|l|}
\hline Rockwell Scale & Indenter & Load (kg) \\
\hline C & Diamond Cone & 150 \\
\hline A & Diamond Cone & 60 \\
\hline D & Diamond Cone & 100 \\
\hline F & $1 / 16^{\prime \prime}$ dia. Steel Ball & 100 \\
\hline & $1 / 16^{\prime \prime}$ dia. Steel Ball & 60 \\
\hline
\end{tabular}

From Reference 4 .

Good practice hardness testing requires a minimum thickness for the test specimens. Disturbance of the metal from the indenter should not be visible on the opposite side of the specimen. Data from Reference 5 suggests that retainer ring material (.02 thick) can not be reliably tested if it is softer than $\mathrm{RC}=80$. In other words, a normal Rockwell hardness instrument would not be suitable for testing retainer rings in the hardness range expected.

Furthermore, hardness testing of cylinders, such as the pintle rod, require a correction factor. Reference 3 gives a selection of correcton factors, but none are available for rods the size of the pintle rod. The pintle rod diameter, .187", is less than the smallest, .25", for which a correction is published. 
A. 2.2 SUPEREICIAL HARDNESS TESTERS

A more-suitable instrument for pintle rod-retainer ring quantification would be the superficial hardness tester which uses smaller forces and smaller penetrations. The indenters are essentially the same as the normal Rockwell tester, but the initial force is $3 \mathrm{~kg}$. The units of superficial hardness is in multiples of 1 micron and the scale-weight system is shown below:

\begin{tabular}{|c|l|l|}
\hline Superficial Hardness Scale & Indenter & Test Load (kg) \\
\hline $15 \mathrm{~N}$ & Diamond Cone & 15 \\
\hline $30 \mathrm{~N}$ & Diamond Cone & 30 \\
\hline $45 \mathrm{~N}$ & Diamond Cone & 45 \\
\hline $15 \mathrm{~T}$ & $1 / 16^{\prime \prime}$ dia Steel Ball & 15 \\
\hline
\end{tabular}

A. 2.3 CORRECTIONS

Superficial hardness scales accommodate thinner material. Reference 5 indicates that the R15N scale is usable on .02-thick material softer than $\mathrm{RC}=20$. Also, diameter corrections are given in Reference 5 for pintle rod diameters.

\section{A. 2. 4 CONVERSIONS}

Material specimens of given hardness will "read" differently on the different Rockwell scales. For example, a metal may read $\mathrm{Rc}=30$ when measured with the Rc30 weight/indenter. It would read $R a=65$ with the $R a$ weight/indenter and $15 \mathrm{~N}=75$ on the superficial hardness tester with the $15 \mathrm{~N}$ weight/indenter. A table of conversions can be found in Appendix $B$.

\section{APPENDIX B HARDNESS CONVERSION TABLES}

APPENDIX C HARDNESS TESTING DETAILS 
APRENDIX B

\section{Afiti E 140}

TABLE 6 Approximate Rockwell Hardness Conversion Numbers for Austenitic Stainless Steel Sheets NOTE-These conversions are based on interlaboratory tests conducted on the following grades: Types 201, 202. 301, 302, 304. 41, 305, 316, 316L, 321, and 347. Tempers ranged from annealed to extra hasd for Type 301, with a smaller range of ternpers in the other types. Test coupon thick nesses ranged from approximately $0.1 \mathrm{in}$. (2.5 mm) to $0.050 \mathrm{in}$. (1.27 mm).

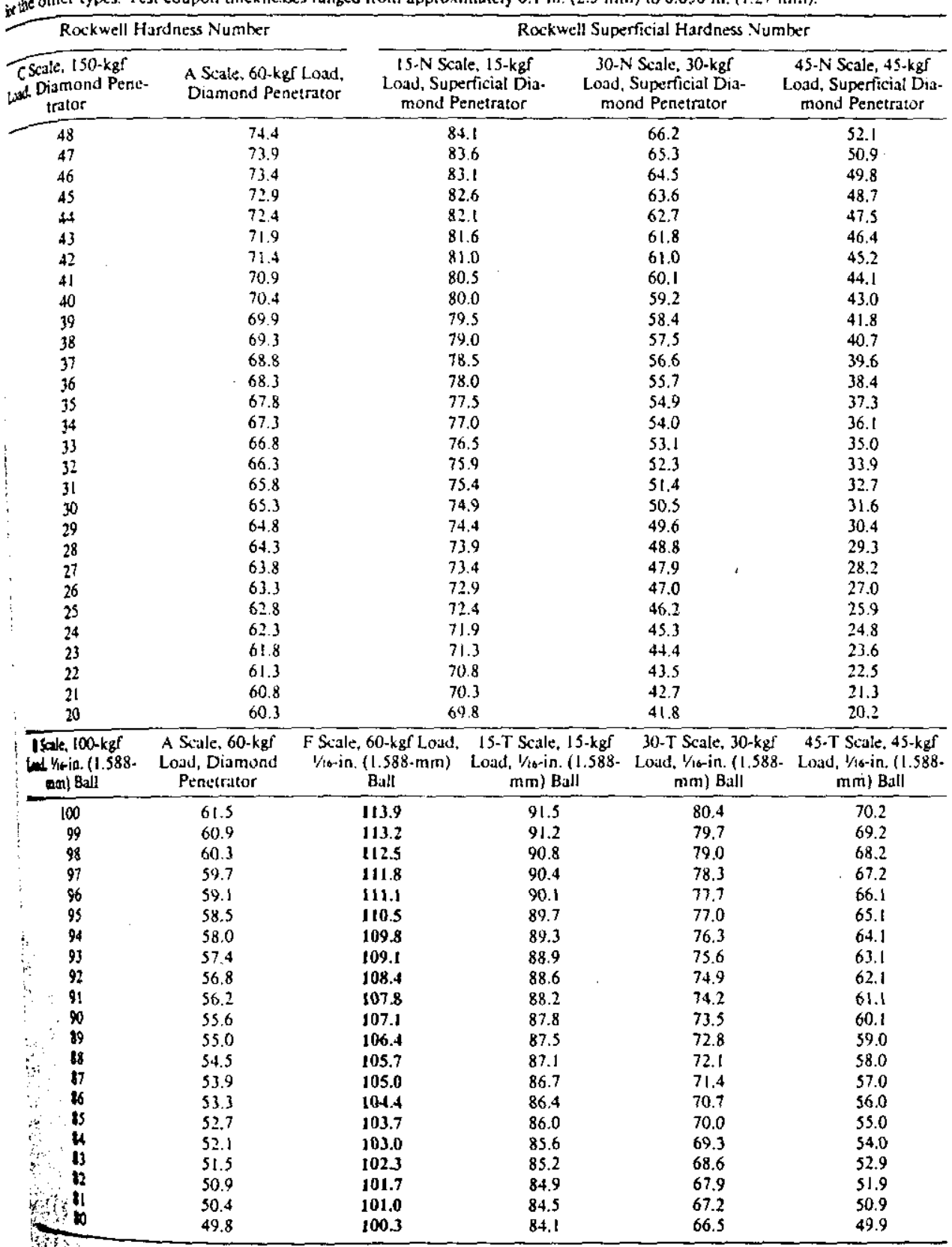


To: File

From: E. B. Schwenk

Subject: INITIAL WORK ON PINTLE ROD-RETAINING RING PROBLEM

\section{A) Review of Notes Taken During Pintle Rod - Retaining Ring Demonstration at 272-AW Machine Shop.}

Paula Deichelborer took me to 272-AW Machine Shop to have Chet Hammack and Fred show me how a retaining ring functions to hold the pintle rod $(1 / 13 / 99)$.

Both gentlemen talked about the "old style" 304 SS (per Rev. 0 on drawing) as the "good stuff." Rev 1,2, and 3 (on the drawing) indicated that the pintle rod material could satisfy either 304 or $304 \mathrm{~L}$ specification. Apparently the Rev 1,2, or 3 material wasn't as good for a given retaining ring to "hold a load" on any pintle rod.

The following information describes ring force gage tests on pintle rod specimens \#1, \#2, and $\# 3$ as demonstrated by Mr. Hammack.

Specimen \#1. Referred to as "fresh old material." It had circumferential scratches that were claimed to have a 40 to $100 \mathrm{rms}$ roughness. A retaining ring was installed. Upon manually applying an axial load (with a ring force gage) the ring broke loose at about 30$\mathrm{lb}$. It should have broken loose at about $100-\mathrm{lb}$ (or more). The gentlemen indicated that the Rockwell $\mathrm{C}$ hardness of the rod was $\mathrm{R}_{\mathrm{C}}=22$ ( $3 \mathrm{rdgs}$ ). [Check to see if this included curvature correction]. Removal of the ring appeared to "shine-up" the rod over which the ring slid off. It also appeared to smooth-up some of the circumferential scratches (must look again under a low-power microscope). According to my notes I said that when the rod was roughened ( 40 to $100 \mathrm{rms}$ ) the release load was increased slightly; this apparently was a comment by one of the gentlemen. According to my notes I wrote down that a $\# 24$ thread file (thread chaser?) was used to roughness the surface of the rod. First the rod was rotated while holding the chaser at $-45^{\circ}$ to the axis of rotation. Then its angle was changed to $+45^{\circ}$. This apparently made cross-hatch type of roughened surface.

Specimen \#2. This was claimed to be new Rev. 0 material, original 304 (no 304L). No surface roughening was done. The average $R_{C}$ was indicated to be 20.2 (avg of 3 rdgs.?). Question: Was any curvature correction added? Rod loaded as above; load went to about $105 \mathrm{lb}$; no movement. Ring released at 45 to $48-\mathrm{lb}$.

Specimen \#3. The specimen was same as \# 2 except hardness was higher $\left(R_{C}=23.5\right.$ (apparently avg. of 3 rdgs.). Check on curvature correction. No surface roughening. Load went to about 105-lb; no movement. Release load about 53-lb. 
B) Pintle Rod Hardness Measurements made on Officine Galileo Machine. (1/21/99).

Specimen \#1. (Shop measurement: $R_{C}=22$, near rod center)

a) Rockwell C Hardness $-150 \mathrm{Kg}\left(\mathrm{R}_{\mathrm{C}}\right) \quad$ Rockwell $15 \mathrm{~N}$ Hardness (HR15N) 17.6, 17.2, and 16.8. Avg: $=17.2 \quad 70.5,71.5$, and 71.2. Avg: $=71.1$

b) Curvature-Corrected Hardness Levels
$R_{C}=17.2+6.5^{1)}$ (est. $)=23.7$
$\operatorname{HR} 15 \mathrm{~N}=71.1+1.0^{2)}=72.1$
1) Corr. From Table 6, ASTM E18-74
2) Corr. From Table 13, ASTM E 18-74.

c) Approx Rockwell Hardness Conversion Numbers for Austenitic SS Sheets: (Per ASTM E 140-84, Table 6)

As-Measured w curv. corr.

$\mathrm{R}_{\mathrm{C}}=23.7$

Curvature-Corrected \& Converted HR15N: $\quad R_{C} \sim 24$

Specimen \#2. (Shop Measurement $R_{C}=20.2$, near rod center)

a) Rockwell C-150 Kg( $\mathrm{R}_{\mathrm{C})}$ :- $\quad$ Rockwell $15 \mathrm{~N}$ Hardness (HR15N) 17.5, 18, and 16.8. Avg. $=17.4 \quad 73.2,74.8,72$, and 73. Avg: $=73.3$
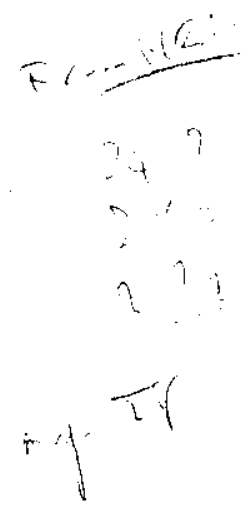

b) Curvature-Corrected Hardness Levels

$$
\begin{array}{lc}
\mathrm{R}_{\mathrm{C}}=17.4+6.5=23.9 & \text { HR } 15 \mathrm{~N}=73.3+1.0=74.3 \\
\text { (Per Table 6, ASTM E 18-74) } & \text { (Per Table 13, ASTM E 18-74) }
\end{array}
$$

c) Approx. Rockwell Hardness Conversion Numbers for Austenitic SS Sheets (Per Table 6, ASTM E 140-84)

As measured w Curv. Corr: $\quad \mathrm{R}_{\mathrm{C}}=23.9$

Curvature-Corrected \& Converted HR15N: $R_{C}=29$

Note: This larger difference between $R_{C}$ and converted HRI5N indicates a harder surface for $\# 2$.

Specimen \#3. $\left(R_{C}=23.5\right.$ near rod center $)$.
a) Rockwell C - $150 \mathrm{Kg}\left(\mathrm{R}_{\mathrm{C}}\right)$ :
19.2, 18.3, and 19.0. Avg: $=18.8$
Rockwell 15 N Hardness (HR15N)
$73.2,72.2$, and 72.0 Avg: $=72.5$

b) Curvature-Corrected Hardness Levels 


$$
\begin{array}{lll}
\mathrm{R}_{\mathrm{C}}=18.8+6.5=25.3 & \text { HR15N }=72.5+1.0=73.5 & 28 \text { of } 64 \\
\text { (Per Table 6 ASTM E 18-74) } & \text { (Per Table 13, ASTM E 18-74) } & \text { RPP-5114 Rev } 0
\end{array}
$$

c) Approx. Rockwell Hardness Conversion Numbers for Austenitic SS Sheets

As-Measured w Curv. Corr: $\quad \mathrm{R}_{\mathrm{C}}=25.3$

Curvature-corrected \& Converted HR15N: $R_{C}=27$

\section{C) Pintle Rod Diameter Measurements}

Diameter measurements were made on Pintle Rods \# 1,2 , and 3 by EBS using a vernier caliper. The measurements were generally orthogonal to each other and made either near the pintle end or near the opposite end.

Dia. $=0.187$ and 0.186 near opp. End.

Dia. $=0.1865$ and 0.186 near pintle end.

Dia. $=0.187$ and 0.1855 -in. (near opp end)

Dia. $=0.186$ and 0.186 -in. near pintle end.

Dia. $=0.186$ and 0.185 near opp. End.

Dia. $=0.186$ and 0.186 near Pintle end.

\section{D) Retaining Ring Dimension Measurements}

Six retaining rings were dimension-measured by EBS with a vernier caliper. Three of the rings had been removed from Pintel Rods 1-3, but were not correlated. That is, the \#1, \#2, and \#3 rings do not necessarily correlate with Pintle rods \#1-3.

Retaining ring \#4, 5, and 6 are virgin and were obtained from Paul Deichelborer; Paul

\begin{tabular}{|c|c|c|c|c|c|}
\hline Ring. No. & $\underline{D}_{\text {Maj. }}$ & $D_{\underline{\text { Min }}}$ & $\underline{\text { Web }-t}$ & Lip Height & Lip Height in Warp Trough \\
\hline 1 & $\begin{array}{l}0.370 \\
0.375\end{array}$ & $\begin{array}{l}0.184 \\
0.185\end{array}$ & $\begin{array}{l}0.012 \\
0.012 \\
0.011\end{array}$ & $\begin{array}{l}0.040 \\
0.052\end{array}$ & 0.040 \\
\hline 2 & $\begin{array}{l}0.373 \\
0.373\end{array}$ & $\begin{array}{l}0.1835 \\
0.184\end{array}$ & $\begin{array}{l}0.012 \\
0.0115 \\
0.011\end{array}$ & $\begin{array}{l}0.041 \\
0.044\end{array}$ & 0.041 \\
\hline
\end{tabular}
apparently obtained about a dozen of them from the 272-AW Shop. EBS measured the OD, ID, web thickness (thickness away from ID-protruding lip), and lip height of all six rings. The lip height was hard to measure for the used rings \#1-3, as the ring removal process caused them to warp (bend out-of- plane). 
3

4

5

6

$\begin{array}{lll}0.3735 & 0.1845 & 0.012 \\ 0.3735 & 0.185 & 0.012 \\ & & 0.01\end{array}$

0.375

0.173

0.012

0.174

0.012

0.012

$\begin{array}{lll}0.375 & 0.172 & 0.0115 \\ 0.375 & 0.172 & 0.0115 \\ & & 0.011\end{array}$

$0.375 \quad 0.173$

0.375

0.173

$$
\begin{aligned}
& 0.050 \\
& 0.040
\end{aligned}
$$

0.040

0.0275

0.0270

0.028

0.028

0.027

0.029
29 of 64

RPP-5114 Rev 0

\section{E) Retaining Ring Hardness Measurements}

Because the rings are so thin (about 0.012-in.) these initial hardness measurements are suspect but are probably good in a relative sense. The hardness measurements on rings \#1-3 are more suspect because they were warped. The 1/4-in (?) dia. anvil would not allow a given portion of the ring to lie flat. Thus some hardness numbers are too low as can be seen. Initially Mr. Sells (Advance Tech. Svs) and I conducted Rockwell A measurements on \# 4 - \#6 rings but found that the reverse-side indent was most noticeable. We than went to the HR $15 \mathrm{~N}$ system and found that the backside-mark still appeared but was smaller. Thus, the HR15N measurements are speculated to be better

\begin{tabular}{|c|c|c|}
\hline Ring No. & $\mathrm{HR} 15 \mathrm{~N}$ & Comment \\
\hline \multirow[t]{5}{*}{$\# 1$} & 47 & Used $1 / 4$-in. dia. anvil on warped \#1-3 rings. \\
\hline & 6 & Ring prob. not flat \\
\hline & 64.8 & \\
\hline & $76\left(\mathrm{R}_{\mathrm{C}} 32\right)^{*}$ & \\
\hline & & \\
\hline \multirow[t]{3}{*}{$\# 2$} & 47 & \\
\hline & 53.5 & \\
\hline & 59 & \\
\hline \multirow[t]{4}{*}{$\# 3$} & 54 & \\
\hline & 58 & \\
\hline & 17 & meas. prob. made in warp \\
\hline & 46 & \\
\hline \multirow[t]{2}{*}{$\# 4$} & 65.2 & Note: we used a flat anvil for rings \#4-6. \\
\hline & 62.5 & \\
\hline \multirow[t]{3}{*}{$\# 5$} & 53.5 & \\
\hline & 49 & \\
\hline & 51.5 & \\
\hline \multirow[t]{3}{*}{$\# 6$} & 47 & \\
\hline & 48 & \\
\hline & 48.5 & \\
\hline
\end{tabular}
(but still relative).
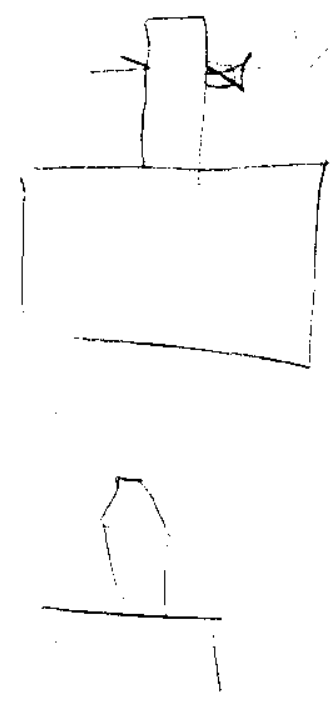
"HR $15 \mathrm{~N}$ conversion to $R_{C}$ taken from ASTM E 140-84. Note that a

HR15N measurement of about 70 is the lowest value that can be converted to an $R_{C}=20$. Values less than 70 don't exist as they would be equivalent to $R_{C}$ values $<20$. Thus, one must make HR15T (1/16-in. dia. ball) indentor measurements in order to convert the HR15T measurements to Rockwell B values.

Note: There is a fair amount of scatter in the hardness data. Some may be related to the backside-denting but part of it is probably real. I must try the 1/16-in. dia. ball (15-T) superficial indentor. 
Date: Jan 29, 1999

To: File

From: E. B. Schwenk

Subject: $2^{\text {nd }}$ CUT AT PINTEL-RETAINING RING HARDNESS EVALUATION

On $1 / 27$ and $1 / 28$ I conducted additional hardness measurements on the retaining rings $(1 / 27)$ then on the Pintel rods (1/28). Here's the data.

\section{1) Calibration}

I put in the C-Brale indentor $(150-\mathrm{Kg})$ and checked the $\mathrm{R}_{\mathrm{C}}$ readings on the $26.5 \pm 1$ and the $44.4 \pm 1$ hardness blocks both on the 2-in. dia. flat anvil. They are (after throwing away the first rdg):
$\underline{\mathrm{R}} \mathrm{c}=26.5$ Block
$\underline{\mathrm{R}_{\mathrm{c}}}=44.4$ Block
$27.5 \& 26.0$ (OK)
$43.5 \& 44.5(\mathrm{OK})$

Next I put the N-Brale indentor $(15 \mathrm{Kg})$ in the Officine Galileo hardness machine and made hardness impressions in the $R_{C}=26.5$ block. The readings are:

$\mathrm{R}_{\mathrm{c}}=26.5$ Block

$72,71.8,71.5(\mathrm{OK})$ [Note: these values are approximately equivalent to $R_{C}=24$, from Hardness Conversion Table]

\section{2) Repeat Retaining Ring Hardness Measurements (Made with New, Small $<1 / 4$-in. dia. Anvil)}

\section{Ring No. HR15N Avg. Rc $\mathrm{R}_{\text {Conversion }}$ Comment}

1) (warped) 69

66

63

56.5

65

2) (warped) 66.3

75

73.5

74.5

3) (warped)

69

71.5

71.5

4)

73.9

74.1

74.5
66

$18 ?$

Some of these indents may be showing up (faintly) on the back side. Some indents appear slightly non-round on the indentor side. Probably due to warp in \#1 ring.

Marks do not appear to show-through on back side.

72.2

25

70.7

$+22$

74.2

No show-through.

Impressions do not show-through on opposite side. 
5)

73.0

73.9

73.0

6)

73.2

72.5

78.8

71.0
73.3

27.7

No show-through.
Impressions do not show-through.

32 of 64
RPP-5114 Rev 0

73.9

28

\section{2) Repeat hardness Measurements on Pintel Rods (1/28/99)}

I re-calibrated the Galileo machine on the $R_{C} 26.5$ and 44.4 blocks. OK.

Next I exchanged the flat (2-in.) anvil for our V-block anvil.

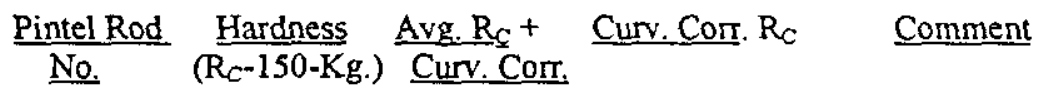

$1 \quad 18.1,19.8$, $19.0,18.5$

20

$2 \quad 21,22$,

$20.8,19.5$

20

$322,23,22$,

$22.3+6.5$
$18.9+6.5$

25.4
Made these measurements about $90^{\circ}$ rotated from first set of measurements.

$-\ldots \quad$ Rotated back $90^{\circ}$

Made these measurements about $90^{\circ}$ 27.8 rotated from first set of measurements.

-.- Rotated back about $90^{\circ}$.

28.8 Rotated about $45^{\circ}$ from initial measurements. s

$21 \quad \ldots \quad$ Rotated back about $45^{\circ}$.

Now exchanging $R_{c}$ Brale indentor for HR15N Brale indentor. Using same V-block anvil. Recalibrated with $R_{C}=26.5$ Block. $H R 15 N$ measurements $=71.0,71.0,71.0$ (OK). 


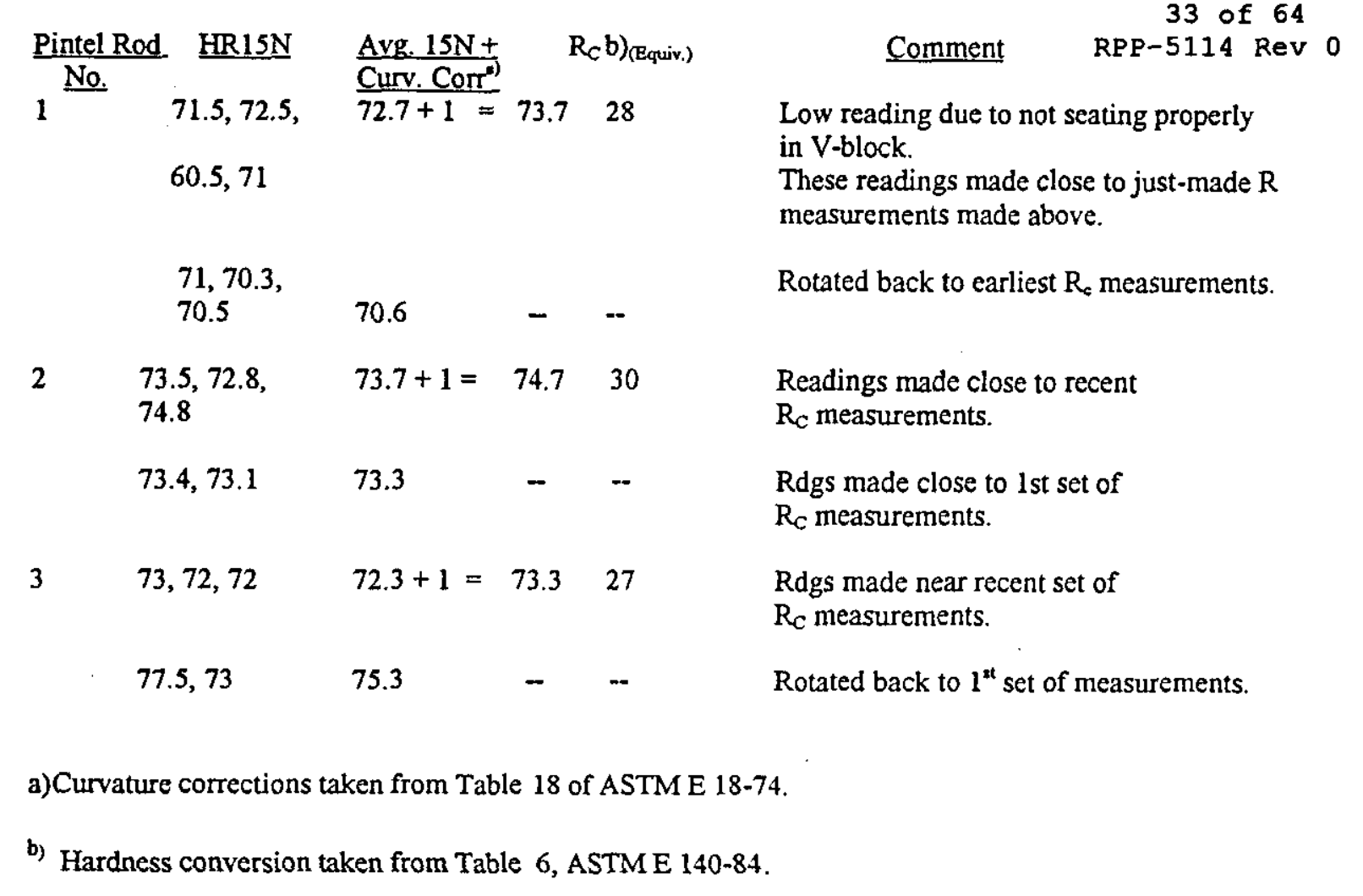


Date: Feb. 3, 1999

34 of 64

RPP-5114 Rev 0

To: File

From: E. B. Schwenk

Subject: WORK HARDENING of 304L and 304 SS and CONVERSION to $R_{C}$

The following Table shows how much both Type 304L and Type 304 SS strongly work harden (i.e., rapidly gain strength with increasing cold work). Further, the data also show and that there are some nominal differences in strength behavior, particularly in the lower cold work ranges (i.e., 0 to $5 \%$ ).

Table 1. Comparison of the Work.Hardening Behavior or Type 304L and Type 304 SS.

Type 304L SS ${ }^{\text {a) }}$

Type $304 \mathrm{SS}^{\mathrm{a})}$

\begin{tabular}{|c|c|c|c|c|c|c|c|}
\hline$\%$ Cold Work & $\begin{array}{l}\text { Y.S. } \\
\text { (Ksi) }\end{array}$ & $\begin{array}{l}\text { U.T.S } \\
\text { (Ksi) }\end{array}$ & $\%$ Cold Work & $\begin{array}{l}\text { Y.S. } \\
\text { (Ksi) }\end{array}$ & $\begin{array}{l}\text { U.T.S. } \\
\text { (Ksi) }\end{array}$ & $\begin{array}{l}\text { Vickers }^{\text {b) }} \\
\text { Hardness }\end{array}$ & $\begin{array}{c}\mathrm{R}_{\mathrm{c}}^{\mathrm{c})} \\
\text { Conversion }\end{array}$ \\
\hline 0 & 33 & 81 & 0 & 35 & 85 & 155 & - \\
\hline 5 & 61 & 95 & 5 & 50 & 90 & 200 & - \\
\hline 10 & 73 & 106 & 10 & 70 & 98 & 225 & $<20 ?$ \\
\hline 15 & 80 & 112 & 15 & 82 & 105 & 260 & 24 \\
\hline 20 & 88 & 122 & 20 & 98 & 112 & 280 & 27 \\
\hline 25 & 107 & 130 & 25 & 107 & 122 & 300 & 30 \\
\hline 30 & 120 & 138 & 30 & 120 & 133 & 315 & 31.5 \\
\hline 35 & 130 & 155 & 35 & 127 & 139 & -- & \\
\hline 40 & 138 & 153 & 40 & 135 & 147 & 335 & 34 \\
\hline 50 & 152 & 169 & 50 & 146 & 159 & 345 & 35 \\
\hline 60 & & -- & 60 & 151 & 167 & 360 & 37 \\
\hline
\end{tabular}

a) From Handbook of Stainless Steel, by D. Peckner and I. Bernstein, McGraw-Hill Book Co., New York, 1977, pp 20-29, Fig. 27.

b) From ASM metals Handbook, Vol. 4, Forming, $8^{\text {th }}$ Edition, 1969, Metals Park, Ohio.

c) Approximate Conversion (based on non-austenitic steel) from ASM Metals handbook, Vol. 8, Mechanical Testing, $9^{\text {th }}$ Edition, pp 84=89, 1985, Metals Park, Ohio.

All the HR15N hardness measurements for the three rods and 12 rings are shown in Table 2, below. 
Date: Feb. 3, 1999

To: File

From: E. B. Schwenk

Subject: $3^{\text {rd }}$ CUT AT RETAINING RING HARDNESS EVALUATION

On 2/3/99 I conducted HR15N (Brale Indentor) measurements on six (6) additional rings (numbered 7 to 12). These were from the original batch that $P$. Deichelborer had gotten for me, apparently from the 272-AW shop.

\section{1) Calibration}

I used both the $R_{C}=34.9 \pm 1$ block and the $R_{C}=26.5 \pm 1$ block for calibrating the HR15N scale.

The measurements on the 34.9 block were:

$76.5,76.9$, and 76

The measurements on the 26.5 block were:

$72,71,71$.

2) New Retaining Ring Hardness (HR15N) Measurements

$\underline{\text { Ring. No. }} \underline{\text { HR15N Avg }} \mathrm{R}_{\mathrm{C}}$ Conversion $\quad \underline{\text { Comment }}$

7) 76.3

76

75.8

76

32

8) 72.5

73.5

73

73

26

9)

72.5

74.5

73

73.3

27

10)

73

79

73

75

30

11)

75

76.5

77

76.2

32.5

12)

\section{4}

74.5

74.5

74.3

29 
Table 2 Grand Average of HRN15 Hardness Values - Converted to Rockwell e6 of 64 RPP-5114 ReV 0

$$
\text { Pintel Rods }(\# 1,2, \& 3)^{(\mathrm{a})} \quad \text { Retaining Rings }(\# 1-12)^{(\mathrm{b})}
$$

Max.

30

28

Avg.

Min.
32.5

27.2

18

a) Total No. of measurements: 22

b) Total No. of measurements: 38 .

c) Note also that rings 1,2, and 3 had been warped as a result of being removed from Rod 1, 2, \& 3; there is no correlation between PR No. and Ring. No. for the first three rings.

\section{RESULTS}

The results shown in Table 2 indicate that the hardness values of the rods and rings are similar but that the rings have a wider range of hardness values. This latter point may be the reason why some rings do not 'bite' into a given rod. For example, a $R_{C} 18$ interference fit ring will not likely plastically indent a $R_{C} 30$ rod. Correspondingly, a $R_{C}$ 32.5 ring might be able to indent all of the pintel rods (assuming none have a hardness $>$ $\mathrm{R}_{\mathrm{C}} 30$ ).

It should be noted that all the hardness measurements made on the rings were taken on their flat annular surfaces". Furthermore, these 'flat' hardness measurements probably do not accurately reflect the hardness of the more highly-worked curved portion of the ring. The latter is the part of the ring that digs into its mating rod. It is likely however, that the curved region does not have a significantly higher hardness level than its nearby flat region. This effect can be noted in Table 1 above. The $R_{C} 32.5$ value for the flat portion of a given ring corresponds to an approximate cold work level of about $35 \%$. Note that as cold work increases to $40 \%$ and more, that the hardness level does not increase as fast as it did for lower cold-work levels.

\footnotetext{
No superficial hardness measurements could be made in the 'biting' portion of the ring because of its extreme curvature. It is possible to obtain microhardness measurements in this high curvature region but would require metallurgically mounting, sanding, and polishing each ring. This would be costly; in addition, the hardness measurements would be more costly as the time to make the measurements is increased in comparison to the superficial hardness tester that was used.
} 


\section{RECOMMENDATIONS}

The present 'fix' of reducing the hardness of the pintle rods (by a thermal softening treatment) appears to be the most economic way of improving the load-carrying capability of a given ring-rod combination. Successful load-release tests on a number of stress-relieved rods would appear to provide you with a technical basis for ameliorating the problem.

It is recommended that $\mathrm{HR} 15 \mathrm{~N}$ (superficial) hardness measurements be made on statistically significant number of rods and rings that have been shown to meet your loadrelease needs. My assumption is that the hardness range for the rings will be less than the range for the rods. If this is the case, then as additional rods or additional rings are purchased, they could be hardness-checked as a quality assurance measure. If their hardness ranges are not satisfactory, and there load-release values are also unsatisfactory, then we should have a technical basis for again applying a thermal treatment to the rods assuming that their surface hardness (or overall hardness) is too high. Or, correspondingly, just reject the components that don 't meet the desired hardness ranges. 
From: E. B. Schwenk

\section{Subject: RESULTS OF PINTLE-ROD AND RETAINING RING HARDNESS EVALUATION [DRAFT]}

\section{INTRODUCTION}

Three pintle rods and 12 retaining rings were hardness-evaluated to see if superficial hardness measurements might provide an explanation of why some previous rod-ring combinations displayed a reduced release load. Hardness measurements made included standard Rockwell ' $\mathrm{C}$ ' and superficial hardness (HR15N) all made on an Officine Galileo Hardness machine located at building $306 \mathrm{E}$. Only the HR $15 \mathrm{~N}$ measurements were used for assessing possible hardness disparities between rod and ring. Standard Rockwell C measurements tended to parallel the HR $15 \mathrm{~N}$ measurements but provided only a relative measure of hardness.

These HR15N measurements, on the subject items, showed trends that may explain why premature release occurred.

\section{RESULTS}

HR $15 \mathrm{~N}^{(\mathbf{a})}$ hardness measurements were made on three pintle rods and 12 retaining rings. Three of the retaining rings had each been pulled off their respective three pintle rods. No correlation was maintained between rod and ring. That is, ring \#1 may have come off $\operatorname{rod} \# 1,2$, or 3 . This however, did not negate the results of the hardness tests.

Twenty-two HR $15 \mathrm{~N}$ hardness measurements were made on the three pintle rods and 38 measurements made on the 12 retaining rings. The results, converted to Rockwell $C\left(R_{C}\right)$ are shown in Table 1.

Table 1 Grand Average of HRN15 Hardness Values - Converted to Rockwell C

$$
\text { Pintle Rods (\#1, 2, \& 3) Retaining Rings (\#1-12) }
$$

Max. $\quad 30$

Avg.

Min. 24

18

(a) Superficial hardness measurements made with a $15-\mathrm{Kg}$. load and a diamond or ' $\mathrm{N}$-Brale' indentor. 
The results shown in Table 1 indicate that the hardness values of the rods and rings are similar but that the rings have a wider range of hardness values and a higher maximum value. This latter point may be the reason why some rings do not 'bite' into a given rod. For example, a $R_{C} 18$ interference fit ring will not likely plastically indent a $R_{C} 30$ rod. Correspondingly, a $R_{C} 32.5$ ring might be able to indent all of the pintle rods (assuming none have a hardness $>R_{c} 30$ ).

It should be noted that all the hardness measurements made on the rings were taken only on their flat annular surfaces". Furthermore, these 'flat' hardness measurements probably do not accurately reflect the hardness of the more highly-worked curved portion of the ring. The latter is the part of the ring that digs into its mating rod. However, it is likely that the curved region does not have a significantly higher hardness level than its nearby flat region. This effect can be noted in the appended Table 2 below. The $R_{c} 32.5$ value for the flat portion of a given ring corresponds to an approximate cold work level of about $35 \%$. Note that as cold work increases to $40 \%$ and more, that the hardness level does not increase as fast as it did for lower cold-work levels.

Not knowing the actual hardness of the 'biting lip' is probably not critical because we do not know how much higher the lip hardness has to be, relative to the rod surface hardness, to provide a satisfactory release load. Thermal stress relief treatments have already been done on some of the remaining pintle rods and have likely been tested for their release loads. If the release loads are satisfactory, it is recommended that additional superficial hardness measurements be made on these successful rod-ring combinations to see what their hardness 'windows' looks like. Most likely, they will display less overlap. If this is the case, then 'quality assurance' superficial hardness measurements on given batches of rods and rings may provide a means for minimizing the premature release problem.

\section{SUMMARY}

An undesirable overlap in the hardness 'windows' for the rods and rings may have contributed to the problem of low release loads. Reducing the hardness range for the pintle rods may be a way for managing the low release load problem.

\section{RECOMMENDATIONS}

If a reduction in the hardness range for the pintle rods does solve the low release load problem, then superficial hardness measurements on successful rod-ring combinations may provide a means for either acceptance/rejection testing of new products, or a guide for applying thermal stress relief treatments to already available products.

\footnotetext{
No superficial hardness measurements could be made in the 'biting' portion of the ring because of its extreme curvature. It is possible to obtain microhardness measurements in this high curvature region but this would require metallurgically mounting, sanding, and polishing each ring. This would be costly; in addition, the hardness measurements would be more costly as the time to make the measurements is increased in comparison to the superficial hardness tester that was used.
} 
The following Table shows how much both Type 304L and Type 304 SS strongly work harden (i.e., rapidly gain strength with increasing cold work). Further, the data also show and that there are some nominal differences in strength behavior between the two alloys, particularly in the lower cold work ranges (i.e., 0 to $5 \%$ ).

Table 2. Comparison of the Work Hardening Behavior or Type 304L and Type 304 SS.

\begin{tabular}{|c|c|c|c|c|c|c|c|}
\hline \multicolumn{2}{|c|}{ Type $304 L$ SS $^{\text {a) }}$} & \multicolumn{6}{|c|}{ Type $304 \mathrm{SS}^{\mathrm{a})}$} \\
\hline$\%$ Cold Work & $\begin{array}{l}\text { Y.S. } \\
\text { (Ksi) }\end{array}$ & $\begin{array}{l}\text { U.T.S } \\
\text { (Ksi) }\end{array}$ & $\%$ Cold Work & $\begin{array}{l}\text { Y.S. } \\
\text { (Ksi) }\end{array}$ & $\begin{array}{l}\text { U.T.S. } \\
\text { (Ksi) }\end{array}$ & $\begin{array}{l}\text { Vickers }{ }^{b)} \\
\text { Hardness }\end{array}$ & $\begin{array}{c}\mathrm{R}_{C}^{\mathrm{c})} \\
\text { Conversion }\end{array}$ \\
\hline 0 & 33 & 81 & 0 & 35 & 85 & 155 & - \\
\hline 5 & 61 & 95 & 5 & 50 & 90 & 200 & - \\
\hline 10 & 73 & 106 & 10 & 70 & 98 & 225 & $<20$ ? \\
\hline 15 & 80 & 112 & 15 & 82 & 105 & 260 & 24 \\
\hline 20 & 88 & 122 & 20 & 98 & 112 & 280 & 27 \\
\hline 25 & 107 & 130 & 25 & 107 & 122 & 300 & 30 \\
\hline 30 & 120 & 138 & 30 & 120 & 133 & 315 & 31.5 \\
\hline 35 & 130 & 155 & 35 & 127 & 139 & - & \\
\hline 40 & 138 & 153 & 40 & 135 & 147 & 335 & 34 \\
\hline 50 & 152 & 169 & 50 & 146 & 159 & 345 & 35 \\
\hline 60 & & - & 60 & 151 & 167 & 360 & 37 \\
\hline
\end{tabular}

a) From Handbook of Stainless Steel, by D. Peckner and I. Bernstein, McGraw-Hill Book Co., New York, 1977, pp 20-29, Fig. 27.

b) From ASM metals Handbook, Vol. 4, Forming, $8^{\text {th }}$ Edition, 1969, Metals Park, Ohio.

c) Approximate Conversion (based on non-austenitic steel) from ASM Metals handbook, Vol. 8, Mechanical Testing, $9^{\text {th }}$ Edition, pp 84=89, 1985, Metals Park, Ohio. 
Date: Feb. 10, 1999

41 of 64

To: File

RPP-5114 ReV 0

From: E. B. Schwenk

Subject: $5^{\text {th }}$ CUT AT EVALUATING PINTLE RODS

On Feb. 8 and 9, 1999 I looked at a number of heat-treated pintle rods using a low-power stereo microscope located in the high-bay region of $306 \mathrm{E}$ bldg. The rods ranged in length from about 5 to 9 -in. Here is a list of my observations. The designation A), B), etc. is what I used to separate one set of rods from another.

A) Knurled Rods ( 1 end) -5 notches ground into each rod. (In plastic ziplok bag)

I designated one rod as $5 \mathrm{~N}-1$, the other $5 \mathrm{~N}-2$. The attached Beaver Heat Treat card said: 1/12/99. P.O. No. P09-002, $R_{C}$ 16-17. The inspector was Dan; the apparent exposure temperature was 1150 (I presume this means ${ }^{\circ} \mathrm{F}$ ). No exposure time noted. Both rods have a light-blue tinge. Each is relatively smooth (except for knurling and retaining ring areas) and has an estimated finish of about 32 microinch more or less.

Specimen $5 \mathrm{~N}-1$ had two (2) hardness marks (impressions) about 1-3/4-in. from the knurled end and another 2 marks about $3 / 8$-in. from the same knurled end. The rod also had a 'white' 1 written on it.

Specimen $5 \mathrm{~N}-2$ has 3 impressions about 3/8-in. from the knurled end and another 2 about $3 / 4$-in. from the same end.

B) Two Rods each with 4-notches ground into each rod (In plastic ziplok bag)

I designated one rod as $4 \mathrm{~N}-1$ the other as $4 \mathrm{~N}-2$. Both rods had a thin, mottled oxide layer (probably angstroms thick). The Beaver Heat treat data card indicated PO9-0002, $1 / 12 / 99$ with a $R_{C}$ of 22 . Inspected by Dan and 1050 (probably for ${ }^{\circ} \mathrm{F}$ ). No time noted.

Specimen $4 \mathrm{~N}-1$ has a 'white' 1 on it. The end opposite the 4-notches was apparently machine-wire brushed (circumferentially). It also shows a $360^{\circ}$ depression about $1 / 4$-in. from the non-notched end. Apparently the ring grabbed securely. The opposite end (oxidized) may have had a ring put on it. It did not leave a depression as deep as the other. I did not see any hardness indents.

Specimen $4 \mathrm{~N}-2$ has a 'white' 2 on it. About $1 / 2$ of this rod was machine wire-brushed. Seven hardness impressions range from about 1 -in. to 1 and $3 / 4$-in. from the unnotched end (also in the machine-brushed area). Three of the impressions appear to have been made before wire brushing (they appear fuzzy) [one farthest from the end and two about intermediate from the same], the remaining four made after brushing. A ring was 
apparently put on the unnotched end but appears to have left only 4 depressions, each separated about $90^{\circ}$.

C) Two Rods each with 6 notches ground into them. (In plastic ziplok bag)

Both of these rods have a light yellow tinge. The Beaver Heat Treat card says PO9-0002, date $1 / 12 / 99$. $R_{c}$ was 13 . Inspected by $D$ an and 1250 (presumably ${ }^{\circ} \mathrm{F}$ ). No exposure time noted.

Specimen $6 \mathrm{~N}-1$ is finely knurled at one and has a 'white' 1 in its center. The end with the notches is opposite the knurled end. There are 6 hardness impressions. The 2 indents nearest the middle of the specimen (farthest from knurled end) appears to have been made after some circumferential abrasion. The remaining 4 indents (closer to the knurled end) appear to have been made without any prior circumferential abrasion or wire brushing. The knurled end (about $1 / 2$-in. long) appears to have had a ring placed on it then removed; it was placed about 0.4 -in. in from the knurled end.

Specimen $6 \mathrm{~N}-2$ has more coarse knurling on both of its ends. The knurled end, opposite the 6 notches appears to have had a retaining ring placed about $0.4-\mathrm{in}$. on, from the end of the rod, then removed. Five hardness indents were seen from about 0.2 -in. to about 0.8 in. from the same ringed and knurled end.

\section{D) Two Rods each with 7 Notches Ground into them (In plastic ziplok bag)}

Both rods have a light, mottled oxide layer (probably angstroms thick) much like those noted in B) above. Each hád about a 1 -in. long circumferentially machine-brushed area closest to their unnotched ends. The Beaver Heat treat data card indicated PO9-0002, Date 1/13/99. They were icspected by ' $L$ ' and had an $R_{C}$ of 20-21. 1100 and 3-hrs were also noted (presumably temperature and time of exposure).

$$
\text { i: }
$$

Specimen $7 \mathrm{~N}-1$ had 6 hardness impressions in its machine-brushed region. Two were fuzzy indicating that they were probably made before brushing (one additional was in the oxide area). Two hardness impressions were apparently made after brushing. One additional indent, near the latter two was apparently made after its region was further abraded, probably with a file. One ring was apparently put on the unnotched end. Its 'depression' was somewhat serpentine indicating that it was warped upon its initial attachment and was removed while in its warped state. The depression did, however, cover the entire $360^{\circ}$ of the rod.

Specimen $7 \mathrm{~N}-2$ has 8 hardn 2 ss impressions: 4 apparently made before wire brushing and 4 afterwards. All 8 are nearest the unnotched end. Two of the four, made afterward, were in the brushed area; the other two appear to have been made after further filing of the machine-brushed region. A ring appears to have been put on the unnotched end and then removed. It did not leave a significant depression but did scratch off much of the very thin oxide layer. 


\section{E) Five Rods light Brown 5114 Rev 0 E) Five Rods, light Brown in Color, no notches. (Secured with Beaver tag and tape)}

Beaver data: Date $1 / 22 / 99$, no P.O. no. noted. 1100 for 3 hrs. Inspected by ' $N$ '? No hardness numbers noted. Also, no apparent hardness rdgs were made. I designated these 5 rods as $\mathrm{LB}$

LB-1. One end (near shear pin hole) appears "chased" with a thread chaser. Deep depression due to biting ring near pin hole end. Depression was serpentine indicating a warping of the ring. The depression showed $360^{\circ}$ around the circumference.

LB-2. The end near the pin hole appears to have had a ring put on and removed. Little circumferential bite noted. Ring only lightly scratched the rod during removal.

LB-3. Ditto LB-2 except it has a deeper depression apparently due to a 'biting' ring $\left(360^{\circ}\right)$. Ring mark is also serpentine indicating that it was warped during its application.

LB-4. Like LB-1. Ring apparently put on and removed. Only left a partial bite over majority of circumference.

LB-5. Some light thread chasing near pin hole end. Ring put on and pulled off. It left a bite over $360^{\circ}$. About $1 / 2\left(180^{\circ}\right)$ was fairly deep, the other $1 / 2$ light.

F) Five Rods Light Blue in Color, no notches, no pin holes. (Secured in nylon : sock-wrap)

Beaver Data: PO9-0002; Date: 1/15/99 ;SR 11003 hrs. Inspected by 'L'? I designated these rods " $B$ ". No hardness impressions noted on all of the rods.

B-1. End opposite vibroetched 'B-1' appeared to have had two different rings attached. One shows a 4-pronged attachment with dig-in marks at $90^{\circ}$ intervals about $3 / 4$-in. from end. A standard ring appeared to have been put on the rod to a point about $1 / 2$-in. from the end. This ring left some light markings (depressions) and had about a $200^{\circ}+$ coverage circumferentially around the rod. I can't tell which ring was put on first as the 4-pronged ring dug deeply into the rod obscuring the previous(or following) standard ring markings.

B-2. This rod had rings attached on both ends. Vibro-etched end has 4 deep marks indicating a 4-pronged ring had been attached asnd removed. The opposite end appears to have had two rings attached and removed. One ring dug in at the typical $90^{\circ}$ positions; the other ring left a serpentine $360^{\circ}$ depression and only scraped a small portion of the rod when being removed.

B-3. This rod had rings attached on both ends. The vibro-etched end had a 4-pronged ring attached, which dug in deep in two of its four locations. The opposite end had a standard ring attached. It dug in lightly over about $180^{\circ}$ and was slightly serpentine in its shape. 
B-4. This rod had only one ring attached on end opposite vibro-etch mark. It was a standard ring; it dug in and left a serpentine depression over the $360^{\circ}$ circumference.

B-5. This rod too had only one ring attached and removed. It appears to have been a standard ring; it dug in lightly over about $180^{\circ}$ of the circumference and was slightly serpentine. 
Date: Feb. 22, 1999

To: File

From: E. B. Schwenk

Subject: $6^{\text {th }}$ CUT AT EVALUATING HARDNESS OF PINTLE RODS

On Feb. 11, 12, and 19 I conducted superficial hardness measurements (Rockwell HR $15 \mathrm{~N}$, using a $15 \mathrm{Kg}$ weight) on 15 pintle rods. They had generally been heat treated (stress-relief annealed) various amounts. On virtually all of the specimens I also made low-power optical observations both before and after HR15N impressions were made. This was done to ensure that the hardness impressions' shape was satisfactory (generally round) and to determine where the impressions were located.

A) Knurled Rods (1 end) -5 notches ground into each rod. $\left(1150^{\circ} \mathrm{F}, \mathrm{R}_{\mathrm{C}} 16-17\right)$

Used $R_{C}$ test block $26.5 \pm 1$ for calibration. Hardness (HR15N) measurements were 72.2 and 72 . These compare well with previous calibration measurements.

1) Specimen $5 \mathrm{~N}-1$. I made hardness indents near "vibroetched" $5 \mathrm{~N}-1$.

\begin{tabular}{|c|c|c|}
\hline Pintle Rod No. & Hardness & Comment \\
\hline $5 \mathrm{~N}-1$ & 65 & Bad rdg; tape on rod \\
\hline & 69.5 & Ok \\
\hline & 70.9 & Ok \\
\hline & 51 & Bad rdg; some tape on rod. \\
\hline & 71 & \\
\hline
\end{tabular}

Avg. hardness $(\mathrm{HR} 15 \mathrm{~N})=70.5+1$ (curvature corr. $)=71.5\left(=\mathrm{R}_{\mathrm{C}} 23+\right)$

2) Specimen $5 \mathrm{~N}-2$. I made hardness indents near "vibroetched $5 \mathrm{~N}-2$.

\begin{tabular}{|c|c|c|}
\hline Pintle Rod. No. & Hardness (HR15N) & Comment \\
\hline 5N-2 & 64 & Bad rdg. \\
\hline & 67.3 & Ok \\
\hline & 70 & Ok \\
\hline & 67 & Ok \\
\hline & 69 & Ok \\
\hline
\end{tabular}

Avg. hardness $(\mathrm{HR} 15 \mathrm{~N})=68.3+1$ (curv. Corr) $=69.3\left(=\mathrm{R}_{\mathrm{c}} \sim 19.5\right)$

Note: I must go back and get hardness measurements in knurled ends.

B) Two Rods each with 4-Notches Ground into Each Rod ( $\left.1050^{\circ} \mathrm{F}, \mathrm{R}_{\mathrm{c}} 22\right)$ )

1) Specimen $4 \mathrm{~N}-1$. 


\begin{tabular}{|c|c|c|}
\hline Pintle Rod No. & Hardness (HR15N) & Comment \\
\hline 4 N-1 & 71 & Machine-brushed end \\
\hline & 72 & Ditto above \\
\hline & 75 & Ditto \\
\hline & & \\
\hline & 71 & $\begin{array}{c}\text { Lightly oxidized end (around vibro-etch } \\
\text { no.) }\end{array}$ \\
\hline & 72.5 & Ditto above \\
\hline
\end{tabular}

Avg. HR $15 \mathrm{~N}$ (machine-brushed end) $=72.7+1$ (curv. corr.) $=73.7\left(=\mathrm{R}_{\mathrm{C}} 27.5\right)$ [Should I get more measurements here?]

Avg. $\mathrm{HR} 15 \mathrm{~N}$ (oxidized end) $=71.8+1$ (curv. corr) $=72.8\left(=\mathrm{R}_{\mathrm{C}} 25.5\right)$

\begin{tabular}{|c|c|c|}
\hline Pintle Rod No. & Hardness (HR15N) & Comment \\
\hline $4 \mathrm{~N}-1$ & 74 & $\begin{array}{c}\text { Bright end (machine-brushed), between end \& } \\
\text { ring indent. }\end{array}$ \\
\hline & 72 & Ditto above \\
\hline & 73 & Ditto \\
\hline & & \\
\hline & 78 & $\begin{array}{c}\text { Opposite end (lightly oxidized) between ring } \\
\text { mark and end of rod. }\end{array}$ \\
\hline & 78.5 & Ditto above \\
\hline & 74 & Ditto \\
\hline
\end{tabular}

Avg. HR15N (bright end) $=73+1$ (curv. corr.) $=74\left(\sim R_{C} 28\right)$

Avg. $\mathrm{HR} 15 \mathrm{~N}$ (mottled end) $=76.8+1$ (curv. corr. $)=77.8\left(\sim \mathrm{R}_{8} 35\right)$ 
2) Specimen $4 \mathrm{~N}-2$

\begin{tabular}{|l|l|l|}
\hline Pintle Rod No. & HR15N & Comment \\
\hline 4N-2 & 74.2 & $\begin{array}{l}\text { These indents made near previous Beaver hardness indents } \\
\text { (machine-brushed area). EBS indents look smaller than } \\
\text { Beavers'; I suspect they used 30 Kg (or more). }\end{array}$ \\
\hline & 74 & Ditto above \\
\hline & 72 & Ditto \\
\hline & 72 & Lightly oxidized end, near vibroetch mark 4N-2. \\
\hline & 71 & Ditto above \\
\hline & 70 & Ditto \\
\hline & 71 & \begin{tabular}{l} 
Machine-brushed area between end \& ring mark. Note that \\
ring appears to have indented heavily in 3 areas but still \\
looks like it was a std. ring. \\
\hline
\end{tabular} \\
\hline
\end{tabular}

Avg. HR15N (machine-brushed end) $=73.4+1$ (curv. corr. $)=74.4\left(R_{C} 29\right)$

Avg. HR $15 \mathrm{~N}$ (machine-brushed end between end \& ring mark) $=72.5+1$

$=73.5\left(R_{C} 27\right)$

Avg. HR15N (lightly oxidized end) $=71+1$ (curv. corr. $)=72\left(R_{C} 24\right)$

C) Two Rods each with 6 Notches Ground into Them $\left.\left(1250^{\circ} \mathrm{F}, \mathrm{R}_{\mathrm{C}} 13\right)\right)$

1) Specimen $6 \mathrm{~N}-1$ (One knurled end, one smooth end)

\begin{tabular}{|l|l|l|}
\hline Pintle Rod No. & HR15N & Comment \\
\hline 6 N-1 & 67 & $\begin{array}{l}\text { Near knurled end; also near hardness indents made by } \\
\text { Beaver (closest to end) }\end{array}$ \\
\hline & 68 & Ditto above. \\
\hline & 67 & Further away from knurled end near $2^{\text {nd }}$ set Beaver marks. \\
\hline & 69 & Ditto above \\
\hline & 67 & Further away from knurled end but outside of filed area. \\
\hline & 58.5 & Inside filed area. \\
\hline & 63 & Also in filed area. \\
\hline & 60 & Ditto above \\
\hline & 64 & Ditto \\
\hline & 72 & $\begin{array}{l}\text { In knurled region, clean end (unabraded by ring); indents } \\
\text { made in 'valley' and into 'land.' }\end{array}$ \\
\hline
\end{tabular}




\begin{tabular}{|l|l|l|}
\hline & 74 & Ditto above. \\
\hline & 40.5 & Looks like indent slid off a 'land.' \\
\hline & 74 & Mainly in valley \\
\hline & 74 & $\begin{array}{l}\text { In ring-abraded area in knurled region. Indent centered in } \\
\text { groove but mark spreads into two lands. }\end{array}$ \\
\hline & 73 & \\
\hline & 72.5 & Substantially in land but some groove. \\
\hline & $\begin{array}{l}\text { Note: while hardness measurement differences between the } \\
\text { knurled-clean and knurled-ring-abraded are not large, the } \\
\text { asperities are "knocked-off' in the ring-abraded area. This } \\
\text { clipping of the asperities would be expected to affect the load } \\
\text { required to remove a 2 } \\
\text { clipped asperity regions might have a slight increase in } \\
\text { hardness over the knurled region. }\end{array}$ \\
\hline
\end{tabular}

$\underline{6 \mathrm{~N}-1}$

Avg. HR15N in smooth area near knurled end $=67.8+1$ (curv. corr.) $=$ $68.8\left(\sim \mathrm{R}_{\mathrm{C}} 19\right.$ ?)

Avg. HR15N in smooth, filed area $=61.4+1$ (curv. corr. $)=62.4\left(\mathrm{R}_{\mathrm{C}}<17\right.$ ?)

Avg. $\mathrm{HR} 15 \mathrm{~N}$ in knurled region, non ring-abraded $=73.3+1$ (curv. corr) $=$

$$
=74.3\left(R_{\mathrm{C}} 29\right)
$$

Avg. HR $15 \mathrm{~N}$ in knurled \& ring-abraded region $=73.2+1$ (curv. corr $)=$

$$
=74.1\left(R_{C} 28.5\right)
$$


2) Specimen $6 \mathrm{~N}-2$ (Knurled at both ends, non-notched end had ring attached)

\begin{tabular}{|c|c|c|}
\hline $\begin{array}{l}\text { Pintle Rod } \\
\text { No. }\end{array}$ & HR15N & Comment \\
\hline \multirow[t]{5}{*}{$6 \mathrm{~N}-2$} & 62 & $\begin{array}{l}\text { Indents made near old indents in smooth region; also near } \\
\text { knurled end (opposite other knurled end with } 6 \text { notches). }\end{array}$ \\
\hline & 34 & Ditto above; bad rdg. \\
\hline & 68.5 & $\mathrm{Ok}$ \\
\hline & 64 & Ok \\
\hline & 67 & $\mathrm{Ok}$ \\
\hline \multirow[t]{4}{*}{$6 \mathrm{~N}-2$} & 64 & $\begin{array}{l}\text { Indents in knurled-only region (w } 6 \text { notches). In groove, } \\
\text { spilled out into } 2 \text { lands. }\end{array}$ \\
\hline & 70.5 & Indent $>50 \%$ in a land. \\
\hline & 59 & At corner, biased by slippage toward 2 valleys (bad rdg). \\
\hline & 67 & $\begin{array}{l}\text { Mainly in land but bulged into nearby valley. These } 4 \text { rdgs } \\
\text { are likely biased but indicate that the knurled region is harder } \\
\text { than the smooth region. }\end{array}$ \\
\hline \multirow[t]{6}{*}{$6 \mathrm{~N}-2$} & 69 & $\begin{array}{l}\text { Indents here made in knurled end. Could not find } \mathrm{l}^{\text {st }} \text { indent } \\
\text { among the knurls. }\end{array}$ \\
\hline & 66 & $\begin{array}{l}\text { Both this rdg and above rdg may have been centered in a } \\
\text { valley - hard to see. }\end{array}$ \\
\hline & 75 & $\begin{array}{l}\text { Could not find this indent and one below; must have been in } \\
\text { valleys. }\end{array}$ \\
\hline & 72 & \\
\hline & Nil & $\begin{array}{l}\text { Ring-abraded portion of knurled region. No reading here; } \\
\text { apparently slid off a land. }\end{array}$ \\
\hline & 79 & In valley \\
\hline
\end{tabular}

Avg HR15N in smooth area (near unnothed end) $=65.4+1$ (curv. corr.) $=$

$$
=66.4\left(\mathrm{R}_{\mathrm{C}}<17 \text { ? }\right)
$$

Avg HR $15 \mathrm{~N}$ in knurled-only end ( $\mathrm{w} 6$ notches) = biased value. Actual hardness probably higher due to knurl-work hardening. No accurate measure was possible.

Avg. HR $15 \mathrm{~N}$ in knurled-only end. Number may reflect both lands and grooves. $=70.5+1=71.5\left(R_{C} 22+\right)$

Avg. HR $15 \mathrm{~N}$ in knurled end only + ring-abraded. Numbers hard to get.

One was $=79+1=80\left(R_{C} 40\right)$ 
D) Two Rods with 7 Notches Ground into them No knurling either end $\left(1100^{\circ} \mathrm{F}\right.$ for 3-hrs, $R_{C}$ 20-21)

\section{1) Specimen $7 \mathrm{~N}-1$}

\begin{tabular}{|c|c|c|}
\hline $\begin{array}{l}\text { Pintle Rod } \\
\text { No. }\end{array}$ & $\begin{array}{l}\text { HRN1 } \\
5\end{array}$ & Comment \\
\hline \multirow[t]{5}{*}{$7 \mathrm{~N}-1$} & 78 & $\begin{array}{l}\text { Indent made near end Beaver indent (unnotched end) also in } \\
\text { machine-abraded region. }\end{array}$ \\
\hline & 72 & Made near $2^{\text {nd }}$ Beaver indent. \\
\hline & 71.5 & Made near $3^{\text {rd }}$ indent in filed area. \\
\hline & 70 & Made near $1^{\text {st }}$ Beaver indent. \\
\hline & 72 & Ditto above. (all above in machine-abraded area). \\
\hline & & \\
\hline & & \\
\hline & 70 & Made in lightly oxidized area near 7-notch end. \\
\hline & 70 & Ditto above \\
\hline & & 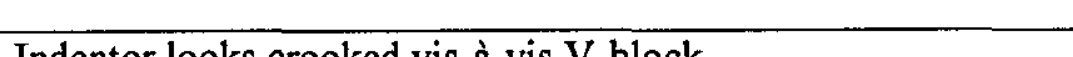 \\
\hline & 20 & Bad rdg (off of diametral line) \\
\hline & 68 & $\begin{array}{l}\text { These last three indents also look distorted. Apparently end of } \\
\text { specimen is bent precluding accurate hardness measurements. } \\
\text { Note that these three measurements were made in region where } \\
\text { ring was removed. }\end{array}$ \\
\hline
\end{tabular}

Avg. HR15N in machine-abraded area $=72.7+1$ (curv. corr. $)=73.7\left(\mathrm{R}_{\mathrm{C}} 27.5\right)$

Avg. $\mathrm{HR} 15 \mathrm{~N}$ in lightly oxidized area $=70+\mathrm{m} 1$ (curv. corr. $)=71\left(R_{C} 22.5\right)$

Avg. HR15N in ring-abraded area could not be made due to distortion in rod end.

Note: I apparently did not do hardness indents on specimen $7 \mathrm{~N}-2$.

\section{2) Specimen $7 \mathrm{~N}-2$}

E) Five brown-tint Rods (No knurling either end but does have thread-chasing) $\left(1100^{\circ} \mathrm{F}\right.$ for 3-hrs)

Only three rods were hardness-evaluated.

1) Specimen LB-1 


\begin{tabular}{|l|l|l|}
\hline $\begin{array}{l}\text { Pintle Rod } \\
\text { No. }\end{array}$ & HR15N & lomment \\
\hline LB-1 & 69 & Near LB-1 vibroetch end. (smooth surface) \\
\hline & 70 & Ditto above. \\
\hline & 68.5 & $\begin{array}{l}\text { Ring-abraded + thread-chased end (opposite to LB-1 } \\
\text { Vibroetch) }\end{array}$ \\
\hline & 67 & Ditto above \\
\hline & & Non-ring-abraded but thread-chased. \\
\hline & 80 & Ditto above. \\
\hline
\end{tabular}

Avg. HR15N for smooth end $69.5+1$ (cruv. corr.) $=70.5\left(R_{C} 21.5\right)$

Avg. HR $15 \mathrm{~N}$ for ring-abraded and thread-chased $=67.8+1$ (curv. corr.) $=$ $68.8\left(\mathrm{R}_{\mathrm{C}}<20\right)$.

Avg. HR $15 \mathrm{~N}$ for non-ring abraded but thread-chased = unclear, probably due to lands and grooves.

2) Specimen LB-5

\begin{tabular}{|l|l|l|}
\hline Pintle Rod LB-5 & HR15N & Comment \\
\hline & 69 & Smooth surface near LB-5 vibroetch. \\
\hline & 71 & Ditto above \\
\hline & 72 & Ditto \\
\hline & & \\
\hline & 65.5 & In thread-abraded and ring-abraded area. \\
\hline & 68 & Ditto above. \\
\hline & & \\
\hline & 70 & Look at rod to determine location. \\
\hline & 69 & \\
\hline
\end{tabular}

Avg. HR15N for smooth surface $=70.7+1$ (curv. corr $)=71.7\left(R_{C} 23.7\right)$

Avg. HR $15 \mathrm{~N}$ in thread-abraded and ring-abraded appear similar to smooth area.

F) Five Rods Light Blue in Color, no notches, no pin holes. (11 we -3 - h/s)

$$
\because \text { ib...tind as int, bl... B. }
$$


1) Specimen B-1

\begin{tabular}{|l|l|l|}
\hline Pintle Rod No. & HR15N & Comment \\
\hline B-1 & 73 & Made on smooth surface near B-1 vibroetch mark. \\
\hline & 68 & Ditto above. \\
\hline & 68 & Ditto \\
\hline & 68 & Ditto \\
\hline & 66 & $\begin{array}{l}\text { Now in ring-abraded area but not quadrifoil area (all close } \\
\text { to opposite end of rod). }\end{array}$ \\
\hline & 68 & Ditto above \\
\hline & 68.5 & Ditto \\
\hline
\end{tabular}

Avg HR $15 \mathrm{~N}$ in smooth surface $=69.3+1$ (curv. corr. $)=70.3\left(\mathrm{R}_{\mathrm{C}} 21\right)$

Avg HR15N in ring-abraded area $=67.5+1$ (curv. corr. $)=68.5\left(\mathrm{R}_{c}<19\right.$ ?)

2) Specimen B-2

\begin{tabular}{|l|l|l|}
\hline Pintle Rod No. & HR15N & Comment \\
\hline B-2 & 69 & Measurements made near vibroetch B-2 mark \\
\hline & 68 & \\
\hline & 70 & \\
\hline
\end{tabular}

Avg. $H R 15 \mathrm{~N}=69+1$ curv. corr. $=70\left(R_{C} 20.5\right)$

G) D. Graves Specimens (Heat-treated to red-heat)

1) Specimen G-1

\begin{tabular}{|l|l|l|}
\hline Pintle Rod No. & HR15N & Comment \\
\hline G-1 & 68 & Hardness measurements made nea vibroetched end (clean) \\
\hline & 72 & Ditto above \\
\hline & 70 & Ditto \\
\hline & & \\
\hline & 51.5 & Hardness measurements made near darkened end \\
\hline & 52 & \\
\hline & 50 & \\
\hline
\end{tabular}

Avg. HR15N for clean end $=70+1$ (curv. corr.) $=71\left(R_{C} 20.5\right)$

Avg HR $15 \mathrm{~N}$ for darkened end $=51.2+1$ (curv. corr. $)=52.2\left(R_{C}<15\right.$ ?) 
2) Specimen G-2

\begin{tabular}{|l|l|l|}
\hline Pintle Rod No. & HR15N & Comment \\
\hline & 70 & Measurements made near clean (vibroetched) end. \\
\hline & 74 & Ditto above. \\
\hline & 69 & Ditto \\
\hline & & \\
\hline & 54 & Measurements made toward middle of dark area \\
\hline & 50 & Ditto above. \\
\hline & 57 & Ditto \\
\hline
\end{tabular}

Avg. HR $15 \mathrm{~N}$ for clean end $=71+1$ (curv. corr. $)=72\left(R_{C} 24\right)$

Avg. $\mathrm{HR} 215 \mathrm{~N}$ for dard end $=53.7+1$ (curv. corr. $)=54.7\left(R_{C}<15\right.$ ?)

\section{3) Specimen G-3}

\begin{tabular}{|l|l|l|}
\hline Pintle Rod No. & HR15N & Comment \\
\hline & 69.5 & Indent made near clean end. \\
\hline & 70.5 & \\
\hline & & \\
\hline & 55 & Indent made near middle of roughened area. \\
\hline & 55.5 & \\
\hline & 55 & \\
\hline
\end{tabular}

Avg. $H R 15 N$ for clean end $=70+1$ (curv. corr.) $=71\left(R_{C} 22.5\right)$

Avg. $\mathrm{HR} 15 \mathrm{~N}$ for middle of roughened area $=55.2\left(\mathrm{R}_{\mathrm{C}}<15\right.$ ? $)$ 
To: File

From: E. B. Schwenk

\section{Subject: $7^{\text {th }}$ CUT AT PINTLE ROD HARDNESS EVALUATION}

On March 1, Paul Deichelborer called indicating that he had some additional failed pintle rods. I left for $2704 \mathrm{HV}$ and accompanied Paul to 272-AW where we picked up the three rods from P. Bryant. All three rods had a blue tint and had cross-hatch, thread-chasing marks on their working ends. The cross-hatching had been placed on the rods before stress-relieving as they had the same blue tint. Based on information attached to each rod I gave them the identifications "FIT-1" (meaning failed-in-test), "RT5-10" (meaning failed retest 5 to 10-1b), and "98-034." Three used retaining rings were included with FIT, one with RT5-10 and one with 98-034. None of the rings left any significant indent in their respective rods.

Calibration: I used the $R_{C}=26.5$ block with the following HR15N results:

1) 72,2$) 72.5$ and 3) 72.5. $\underline{A v g}=72.3\left[R_{c} 25\right.$, from Table 6 ASTM E 140]

a) FIT-1 HR15N measurements were made near center of rod:

1) $=68.2)=70,3)=70 . \underline{\operatorname{Avg}}=69.3+1$ (curv. corr. $)=70.3\left[R_{c} 21\right]$

I noted that the rod is slightly bent by always rolling to one position on a flat surface. It also did not want to turn easily in the hardness machine V-block support. I tried to get hardness measurements on the working end but was not successful due to the cantilever effect.

I then hung a weight on the working end of the rod in order to make hardness measurements closer (about 4-in. away) to the cross-hatched end. 4) $=71,5$ ) = 71.5. I then hung more weight and 1 was able to make two more measurements now about 2-1/2-in. away from the end. 6) $=727)=71$.

$$
\underline{\text { Avg. }}=71.4 \text { (4 rdgs) }+1 \text { (curv. corr.) }=72.4\left[\mathrm{R}_{\mathrm{C}} 25\right]
$$

b) 98-034 This rod was also bent like FIT. Also could not rotate it in V-block without it rotating back to its desired neutral position. The hardness measurements were made near the rod center.

$$
\text { 1) }=70,2)=70,3)=71 \text {. Avg. }=70.3+1 \text { (curv. corr. })=71.3\left[R_{C} 23\right]
$$

I then hung a weight on the working end as before.

$$
\text { 4) }=72,5)=71 \text { Avg. }=71.5+1 \text { (curv. corr.) }=72.5\left[R_{c} 25\right]
$$

(both measurements made about 6-in. from working end).

I added more weight. 
$6)=71.5,7)=71.5 \quad$ Avg. $=71.5+1$ (curv. corr. $)=72.5\left[R_{c} 25\right]$

(both measurements about $1 / 2$-in. from end.

c) RT5-10 This rod would also not freely rotate to any given azimuthal position in the V-block.

$$
\begin{gathered}
\text { 1) }=71,2)=71 \text { Avg. }=71+1 \text { (curv. corr) }=72\left[R_{C} 24\right] \\
\text { (measurements made near center of rod). }
\end{gathered}
$$

I put weight on end as above.

$$
3)=72.5,4)=73,5)=73.5 \quad \text { Avg. }=73 \text { (made about 4-in. from end). }
$$

I added more weight.

$6)=71,7)=72, \underline{\text { Avg. }}=71.5$ (indents made about 3 -in. from end).

Avg. 5 rdgs $)=72.4+1$ (curv. corr.) $=73.4\left[R_{C} 27\right]$

On $3 / 8 / 99$ I cut off the working ends of all three rods in order to make measurements in the abraded areas.

Calibrated as usual on $R_{C}=26.5$ block. 1) $\left.\left.\left.=72,2\right)=73,3\right)=73,4\right)=73$.

d) $\underline{\mathrm{RT} 5-10}$

$$
\text { Avg. }=72.8\left[R_{C} 26\right]
$$

The first four measurements were made in the area closest to the end of the rod where the ring had lightly abraded the rod during insertion/removal.

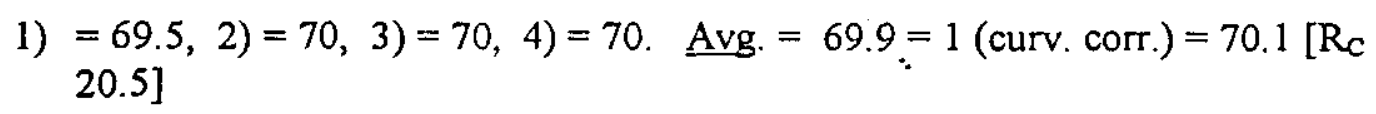

The next three measurements were made in the cross-hatched region where the ring had not disturbed the surface.

$$
5)=70,6)=71,7)=73 . \underline{\text { Avg. }}=71.3=1 \text { (curv. corr. })=72.3\left[R_{C} 25\right]
$$

\section{e) FIT-1}

The measurements were made as in d) above.

$$
\begin{aligned}
& \text { 1) }=71,2)=69,3)=71 \quad \text { Avg. }=70.3+1 \text { (curv. corr. })=71.3\left[R_{C} 23\right] \\
& \text { (All made in ring-abraded area). } \\
& \text { 4) }=69,5)=70,6)=71 \quad \text { Avg. }=70+1 \text { (curv. corr. })=71\left[\mathrm{R}_{\mathrm{c}} 22+\right]
\end{aligned}
$$

(All made in cross-hatched, non-ring-disturbed area).

f) $98-034$

Measurements made as above.

$$
\begin{aligned}
& \text { 1) }=70.5,2) 70,3)=72 \quad \text { Avg. }=70.8+1 \text { (curv. corr. })=71.8\left[R_{C} 24\right] \\
& \text { (ring-disturbed area). } \\
& 4)=74,5)=72,6)=71 . \underline{\text { Avg. }}=72.3+1(\text { curv. corr. })=73.3\left[R_{C} 27\right]
\end{aligned}
$$


To: File

From: E. B. Schwenk

Subject: $8^{\text {th }}$ CUT AT PINTLE ROD HARDNESS EVALUATION

Today I conducted HR $15 \mathrm{~N}$ hardness measurements on retaining rings from FIT-1, RT510 , and $98-034$. I also made measurements on new, failed rods $98-029,-033,-034$, and 036.

Calibration on $R_{C}=26.5$ block.

$1)=71.8,2)=71.5,3)=72$. Avg $=71.8\left(=R_{C} 24\right.$, Table 6, ASTM E 140 $)$

a) FIT-1

1) $1^{\text {st }}$ Ring.

a) $=61$, b) $=65$, c) $=70$, d) $=73.5$, e) $=74, f)=75$, g) $=72.5$

Avg $_{\text {. }}=72.8$ (last 4-rdgs) $\left[=R_{C} 26\right.$, Table 6]

Note: I went counterclockwise around ring.

First two measurements are low - I'm not sure why. When I calibrated the machine I used the flat anvil. I then had to remove the N-Scale indentor in order to make room to fit the small dia. anvil in place. I then did one hardness indent in the 26.5 block before starting on the ring.

2) $2^{\text {nd }}$ Ring

a) $=77$ ?, b) $=74, \mathrm{c})=71, \mathrm{~d})=73, \mathrm{e})=72$

Avg. $=72.5$ (last 4 rdgs) $\left[=R_{C} 25\right]$

3) $3^{\text {rd }}$ Ring

a) $=73, \mathrm{~b})=72.5, \mathrm{c})=71, \mathrm{~d})=72$ I went $\mathrm{CCW}$.

Avg. $=72.1\left[=R_{c} 24.5\right]$

b) RT5-10

1) One ring

a) $=73, \mathrm{~b})=72.5, \mathrm{c})=73.5[\mathrm{CCW}]$

c) $98-034$

$$
\text { Avg. }=73\left[=R_{C} 26\right]
$$

1) One Ring.

a) $=74.5$, b) $=73,3)=72.5$, d) $=75.5[\mathrm{CCW}]$

$\underline{\text { Avg. }}=73.9\left[=R_{C} 28\right]$

d) New Rod 98-029

1) $=70,2)=71,3)=70.5$ (all taken near rod center) 
Avg. $=70.5+1$ (curv. corr.) $=71.5\left[R_{c} 23.5\right]$

e) New Rod 98-033

1) $=69,2)=69,3)=68.5$ Rod not bent; sits in any position in V-block.

Avg. $=68.8+1$ (curv. corr. $)=69.8\left\{=R_{c} 20\right]$

f) New Rod 98-034a Rod is bent slightly; seeks one orientation.

1) $=70,2)=69.5,3)=70$

$\underline{\text { Avg. }}=69.8+1$ (curv. corr. $)=70.8\left\{=R_{C} 22\right]$

g) New Rod 98-036

1) $=69.5,2)=70.5,3)=68,4)=68.5 \quad$ Rod is bent

$\underline{\text { Avg. }}=69.1+1$ (curv. corr.) $=70.1\left[R_{C} 20.5\right]$

h) Ring from $98-029$

1) $=7 \mathrm{l}, 2)=70,3)=72 \mathrm{CCW}$

Avg. $=71\left[R_{C} 22.5\right]$

i) Ring from 98-033

1) $=72,2)=72,3)=72 . \mathrm{CCW}$ Avg. $=72\left[R_{C} 24\right]$

j) Ring from $98-034 a$

1) $=69,2)=71,3)=72 . \mathrm{CCW}$

$\underline{\text { Avg. }}=70.7\left[\mathrm{R}_{\mathrm{C}} 22\right]$

k) Ring from $98-036$

1) $=69,2)=70,3)=71 . \mathrm{CCW}$

$\underline{\text { Avg. }}=70\left[R_{C} 20.5\right]$

More new rods and rings.

a) 98-010 Ring

1) $=69,2)=70,3)=74,4)=72 \mathrm{CCW}$

Avg. $=71.3\left[R_{C} 23\right]$

b) 98-013 Ring

1) $=71.5,2)=75,3)=72.5,4)=74$. CCW first then back due to curvature. Avg. $=73.3\left[R_{C} 27\right]$

c) 98-016 Ring

1) $=64 ?, 2)=74,3)=74,4)=71.5$. I went $\mathrm{CCW}$ on $1^{\text {st }} 3$ then backed up due Avg. $=73.2$ (avg. of 2-4) $\left[R_{C} 26.5\right] \quad$ to curvature. 
d) 98-010 Rod

1) $=70,2)=70,3)=70$. Rod is bent slightly. Rdgs taken near cenfe?-5114 Rev 0 $\underline{\text { Avg }}=70+1$ (curv. corr.) $=71\left[R_{c} 22.5\right]$

e) 98-013 Rod.

1) $=70,2) 69.5,3)=70$ Rod is bent slightly. Avg. $=69.8+1$ (curv. corr. $)=70.8\left[R_{C} 22\right]$

f) $98-016 \mathrm{Rod}$

1) $=69,2)=71,3)=70$. Rod is bent slightly.

Avg. $=70+1$ (curv. corr.) $=71\left[R_{C} 22.5\right]$

$3 / 11 / 99$

I had Tom DeLucchi cut off the ends of new rods 98-029, 98-033, 98-034a, and 98-306. The ends were about 1-1/2 to 2 -in. long. This was done in order to see if these rods had any significant difference in hardness between the middle and their working end (see significant difference in hardness between middle and end for FIT-1, RT5-10, and 98034).

Calibration of $H R 15 \mathrm{~N}$ on $R_{C} 26.5$ block. 1$\left.\left.)=72.5,2\right)=73,3\right)=73$.

$\underline{\text { Avg. }}=72.8\left[R_{C} 26\right]$

a) Rod End $98-029$

1) $=69,2)=58 ?, 3)=72,4)=69$. These rdgs taken in ring-abraded area.

Avg. $=70(3$ rdgs $)+1$ (curv. corr. $)=71\left[R_{C}=22.5\right]^{:}$

5) $=68,6)=68,7)=70.5$. These rdgs taken in cross-hatched but non ring-abraded area.

$\underline{\text { Avg. }}=68.8(3 \mathrm{rdgs})+1$ (curv, . corr. $)=69.8\left[\mathrm{R}_{\mathrm{C}} 20\right]$

b) Rod end 98-033

1) $=70,2)=72,3)=71.5$. (These rdgs taken in ring-abraded area) $\underline{\text { Avg. }}=71.5+1$ (curv. corr.) $=72.5\left[R_{c} 25\right]$

4) $=70.5,5)=69,6)=70$ (These rdgs taken in cross-hatched, non ring-abraded area)

Avg. $=70.5+1$ (curv. corr.) $=71.5\left[R_{c} 23+\right]$

c) Rod end 98-034a

1) $=68.5,2)=68,3)=69$. (Ring-abraded area)

Avg. $=68.5+1$ (curv. corr.) $=69.5\left[R_{C} 20-\right]$

5) $=68,5)=70.5,6)=71$ (Cross-hatched area, non ring-abraded)

$\underline{\text { Avg }_{\mathrm{.}}}=69.8+1$ (curv. corr. $)=70.8\left[\mathrm{R}_{\mathrm{C}} 22\right]$ 
d) Rod end 98-036

1) $=74,2)=74,3)=71$. (Ring-abraded area)

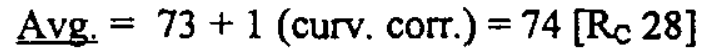

4) $=70,5)=71,6)=70$. (Cross-hatched, non ring-abraded area)

Avg. $=70.3+1$ (curv. corr) $=71.3\left[R_{C} 23\right]$

2: 45 PM. I went back to the high bay and got Marty Casto to cut off the "grab end" of the above four rods. I did this to see if there is an end-to-end variation in hardness. The pieces are about 3-4-in. long.

a) Rod end 98-029-1 (Grab end) The hardness indents started about 3/4-in. from the

1) $=66,2)=67,3)=68.5,4)=66.5$

weld joining the rod to the grab end.

Avg. $=67(4$ rdgs $)+1$ (curv. corr. $)=68\left[R_{C}<19\right]$

b) Rod end of 98-033-1 (grab end) The indents started about 3/4-in. from weld.

1) $=69,2)=68,3)=69$.

$$
\text { Avg. }=68.7(3 \mathrm{rdgs})+1 \text { (curv. corr })=69.7\left[\mathrm{R}_{\mathrm{c}} 20\right]
$$

c) Rod end of 98-034a-1 (grab end) The indents started about 3/4-in. from weld.

1) $=67.5,2)=70,3)=70.5,4)=70,5)=68$ Rdgs $1-4$ progressed away from the weld; because the numbers seemed to be monotonically increasing, I backed up and made indent 5 near no. 1 rdg.

$\underline{\text { Avg. }}=69.2(5$ rdgs $)+1$ (curv. corr. $)=70.2\left[R_{C} 21\right]$

d) Rod end of 98-036-1 (grab end) Ditto above.

1) $=68.5,2)=69,3)=69,4)=69$

Avg. $=68.9(4 \mathrm{rdgs})+1$ (curv. corr. $)=69.9\left[\mathrm{R}_{\mathrm{C}} 20\right]$

Calibration check. $R_{C}=26.5$ block. 1$\left.\left.)=72,2\right)=71,3\right)=72$.

Avg. $=71.7$ (3 rdgs) $\left[R_{C} 24-\right]$ 
Date: March 14, 1999

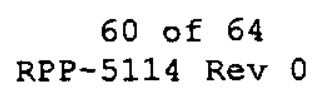

To: File

From: E. B. Schwenk

Subject: COMPARISON OF ROD HARDNESS DATA $\left(9^{\text {th }} \mathrm{Cut}\right)$

1) 5-Notches $1150^{\circ} \mathrm{F}$ for 3-hours, Knurled Rods (1 end) [ $R_{\mathrm{C}} 16-17$, Beaver Data]

\begin{tabular}{|l|l|l|l|l|l|}
\hline Rod No. & Location & & Hardness & & Comment \\
\hline $5 \mathrm{~N}-1$ & Smooth & 24 & Avg. & Min & \\
\hline & $\begin{array}{l}\text { Knurled \&Ring } \\
\text { abraded }\end{array}$ & 40 & 35 & 21.5 & \\
\hline $5 \mathrm{~N}-2$ & Smooth & 22.5 & 19.5 & 30 & $\begin{array}{l}\text { Much harder in knurled } \\
\text { region }\end{array}$ \\
\hline & $\begin{array}{l}\text { Knurled + ring } \\
\text { abraded }\end{array}$ & 44 & 33.5 & 20 & $\begin{array}{l}\text { Much harder in knurled } \\
\text { region. }\end{array}$ \\
\hline
\end{tabular}

2) 4-Notches $1050^{\circ} \mathrm{F}-3$ hours $\left[R_{c} 22\right.$, Beaver Data]

\begin{tabular}{|l|l|l|l|l|l|}
\hline Rod No. & Location & & Hardness & & Comment \\
\hline & & Max. & Avg. & Min. & \\
\hline $4 \mathrm{~N}-1$ & $\begin{array}{l}\text { Machine- } \\
\text { brushed }\end{array}$ & 32 & 27.5 & 24 & \\
\hline & Lightly oxidized & 27 & 25.5 & 24 & \\
& $\begin{array}{l}\text { Machine brushed } \\
\text { \& ring scraped }\end{array}$ & 30 & 28 & 26 & \\
\hline & $\begin{array}{l}\text { Lightly oxidized } \\
\& \text { ring-scraped }\end{array}$ & 39 & 35 & 30 & \\
\hline
\end{tabular}

\begin{tabular}{|l|l|l|l|l|l|}
\hline 4N-2 & Location & & Hardness & & Comment \\
\hline & $\begin{array}{l}\text { Machine- } \\
\text { brushed }\end{array}$ & Max. & Avg. & Min. & \\
\hline & Lightly oxidized & 26 & 29 & 26 & \\
\hline $\begin{array}{l}\text { Machine- } \\
\text { brushed \& ring- } \\
\text { scraped }\end{array}$ & 30 & 29 & 26 & \\
\hline & & & & \\
\hline
\end{tabular}


3) 6-Notches $1250^{\circ} \mathrm{F}-3$ hours $\left[R_{C} 13\right.$, Beaver Data]

61 of 64

RPP-5114 Rev 0

\begin{tabular}{|c|c|c|c|c|c|}
\hline Rod No. & Location & & Hardness & - & Comment \\
\hline & & Max. & Avg. & Min. & \\
\hline \multirow[t]{4}{*}{$6 \mathrm{~N}-1$} & Smooth & 20.5 & $<19$ & $<19$ & \\
\hline & Filed area & $<19$ & $<17$ & $<16$ & \\
\hline & $\begin{array}{l}\text { Knurled end } \\
\text { non ring } \\
\text { abraded }\end{array}$ & 30 & 29 & 26 & \\
\hline & $\begin{array}{l}\text { Knurled end \& } \\
\text { ring abraded }\end{array}$ & 30 & 28.5 & 27 & \\
\hline \multirow{4}{*}{$\begin{array}{l}6 \mathrm{~N}-2 \\
\text { both ends } \\
\text { knurled }\end{array}$} & Smooth & 20 & $<17$ & $<16$ & \\
\hline & $\begin{array}{l}\text { Knurled end w } \\
6 \text {-notches }\end{array}$ & -- & - & -- & $\begin{array}{l}\text { Hardness likely greater; } \\
\text { not possible to get good } \\
\text { measure }\end{array}$ \\
\hline & $\begin{array}{l}\text { Knurled end } \\
\text { (opposite end) }\end{array}$ & 26 & $22+$ & $<18$ & \\
\hline & $\begin{array}{l}\text { Knurled + ring } \\
\text { abraded }\end{array}$ & -- & 40 & -- & $\begin{array}{l}\text { Only one measurement } \\
\text { made. }\end{array}$ \\
\hline
\end{tabular}

4) 7-Notches (no Knurling) $1100^{\circ} \mathrm{F}-3$ hours $\left[R_{C} 20-21\right.$, Beaver Data]

\begin{tabular}{|l|l|l|l|l|l|}
\hline Rod No. & Location & & Hardness & . & \\
\hline $7 \mathrm{~N}-1$ & $\begin{array}{l}\text { Machine- } \\
\text { brushed } \\
\text { region }\end{array}$ & 38 & Avg. & Min & \\
\hline & $\begin{array}{l}\text { Lightly } \\
\text { oxidized } \\
\text { area }\end{array}$ & 22.5 & 22.5 & 22 & \\
\hline & $\begin{array}{l}\text { Ring } \\
\text { abraded area }\end{array}$ & & & 22.5 & \\
\hline $7 \mathrm{~N}-2$ & $\begin{array}{l}\text { Machine } \\
\text { brushed area }\end{array}$ & 30 & 27.5 & 26 & $\begin{array}{l}\text { Could not } \\
\text { get good } \\
\text { rdgs. }\end{array}$ \\
\hline & $\begin{array}{l}\text { Filed } \\
\text { Lightly } \\
\text { oxidized }\end{array}$ & -- & 30 & -- & \\
\hline $\begin{array}{l}\text { Ring- } \\
\text { scraped }\end{array}$ & 29 & 29 & 28 & \\
\hline
\end{tabular}


5) Five Brown-tint Rods (no Knurling but w thread-chasing) $1100^{\circ} \mathrm{F} 3 \mathrm{hrs}$ [No Beaver hardness data]

\begin{tabular}{|c|c|c|c|c|c|}
\hline Rod No. & Location & & Hardness & & Comment \\
\hline & & Max. & Avg. & Min. & \\
\hline \multirow{3}{*}{ LB-1 } & Smooth & 22.5 & 21.5 & 20.5 & \\
\hline & $\begin{array}{l}\text { Ring- } \\
\text { abraded }+ \\
\text { thread } \\
\text { chased }\end{array}$ & $<20$ & $<19$. & $<18$ & \\
\hline & $\begin{array}{l}\text { Non ring- } \\
\text { abraded + } \\
\text { thread } \\
\text { chased }\end{array}$ & 42 & 30 & $<18$ & $\begin{array}{l}\text { Variation } \\
\text { probably due } \\
\text { to lands \& } \\
\text { grooves. }\end{array}$ \\
\hline \multirow[t]{2}{*}{ LB-5 } & Smooth & 26 & 23.7 & 20.5 & \\
\hline & $\begin{array}{l}\text { Thread- } \\
\text { abraded \& } \\
\text { ring abraded }\end{array}$ & 22.5 & About 19 & $<17$ & \\
\hline
\end{tabular}

6) Light Blue Rods (5) $1100^{\circ}$ F-3 hrs. [No Beaver Hardness data]

\begin{tabular}{|l|l|l|l|l|l|}
\hline Rod No. & Location & & Hardness & & Comment \\
\hline & & Max. & Avg. & Min. & \\
\hline B-1 & Smooth & 28 & 21 & 20 & \\
\hline & Ring abraded & $<20$ & $<19$ & $<18$ & \\
\hline & & & & & \\
\hline B-2 & Smooth & 22 & 20.5 & $<20$ & \\
\hline
\end{tabular}


Date: March 17, 1999

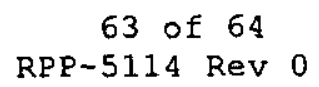

To: File

From: E. B. Schwenk

\section{Subject: $10^{\text {TII }}$ CUT AT PINTLE ROD HARDNESS EVALUATION}

Today I attempted to complete the hardness evaluation on 98-016, 98-013, RT5-10, 98010 , and $98-034$ so that I had end-to-end measurements of hardness on all these rods. I forgot FIT-1.

Calibration on $\mathrm{R}_{\mathrm{C}}=26.5$ block. 1) $\left.\left.=72.5,2\right)=73.5,3\right)=73$. Avg. $=73$

$$
\left(=\mathrm{R}_{\mathrm{C}} 26\right. \text {, ASTM E140, Table 6) }
$$

a) 98-016-1 (Grab End)

1) $=43.5($ low 2$)=61,3)=68,4)=68,5)=69$. Note $1^{\text {st }}$ two indents were in a "different" quality area.

Avg. $=68.3+1$ (curv. corr. $)=69.3\left(R_{C}<20\right)$

b) 98-016 Working end

1) $=$ bad (misaligned $), 2)=68.5,3)=68.53)=\operatorname{misaligned}(56), 4)=68.5$, $5)=68.5, \operatorname{Avg}=68.5+1$ (curv. corr. $)=69.5\left(R_{C}<20\right)$.

$6)=70.5,7)=71,8)=70($ all in thread-abraded area $)$ Avg. $=70.5+1$ (curv. corr. $)=71.5\left(R_{C} 22.5\right)$

$9)=71,10)=72,11)=73.5$ (all in thread-abraded + ring-scraped $)$. Avg. $=72.2+1)$ curv. corr. $)=73.2\left(\mathrm{R}_{\mathrm{C}} 26.5\right)$

c) 98-013-1 (Grab end)

1) Misaligned, 2) $=70,3)=70.5,4)=72,5)=71$. Avg. $=70.8+1$ (curv. corr. $)=71.8\left(R_{C} 24\right)$

d) 98-013 Working end

1) $=69,2)=69,3)=71$. Avg. $=69.7+1($ curv, corr $)=70.7\left(R_{C} 22\right)$

4) $=66,5)=69,6)=70($ all thread-abraded region) Avg. $=68.3+1$ (curv. corr. $)=69.4\left(R_{C}<20\right)$

7) $=70,8)=70,9)=72($ ring abraded + thread chased $)$ Avg. $=70.7+1$ (curv. corr. $)=71.7\left(\mathrm{R}_{\mathrm{c}} 23.5\right)$

e) RT5-10-1 (Grab end)

1) $=70,2)=69.5,3)=76($ high? $)$. Avg. $=71.9+1$ (curv. corr. $)=72.9\left(R_{C} 26\right)$

f) $98-010-1$ (Grab end) 
1) $=69.5,2)=69.5,3)=69$. Avg. $=69.3+1$ (curv. corr. $)=70.1\left(R_{C} 20.5\right)$

g) 98-010 Working End

1) $=69,2)=70.5,3)=71$. Avg. $=70.2+1($ curv. corr. $)=71.2\left(R_{C} 22\right)$

4) $=68,5)=71,6)=70$ (all Thread-chased area) Avg. $=69.8+$

1 (Curv. corr. $)=70.8\left(\mathrm{R}_{\mathrm{c}} 22\right)$

7) $=67.5,8)=69,9)=71$ (all ring-scraped + thread chased). Avg. $=69.2+$ 1 (curv. corr. $)=70.2\left(R_{c} 21\right)$

h) $98-034-1$ (Grab End)

1) $=69,2)=69,3)=70$. Avg. $=69.3+1$ (curv. corr. $)=70.3\left(R_{C} 21\right)$

i) 98-034 Working End

1) $=69,2)=69,3)=69$. Avg. $=69+1$ (curv. corr. $)=70\left(R_{C} 20.5\right)$

4) $=67,5)=66.5,6)=67$ (All thread-chased). Avg. $=66.8+1$ (curv. corr. $)$ $=67.8\left(R_{C}<18\right)$

7) $=69.5,8)=68.5,9)=70($ All ring-abraded + thread chased $)$. Avg. $=69.3$

+1 (curv. corr) $=70.3\left(R_{c} 21\right)$

Note: I think I just repeated $98-034$ working end as there are another 6 or so indents on the rod. 